

\section{Sumário}

EDITORIAL

Bruno Amaral Machado, Camilla de Magalhães Gomes e Soraia Mendes

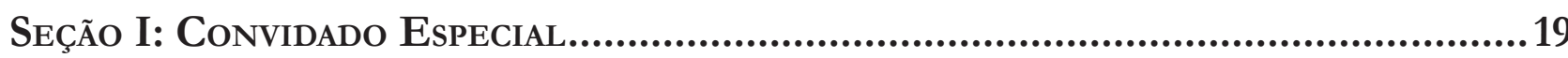

Autonomia Pessoal, Destino, julgamentos e instituições no Brasil: Notas Sobre uma PERGUNTA E ALGUMAS RESPOSTAS

Luiz Edson Fachin

SEÇÃo 2: Dossiê Temático....................................................................................40

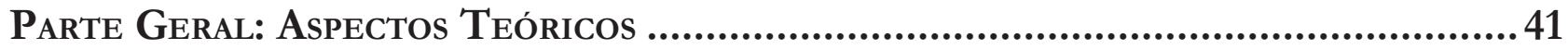

Raça e essencialismo na Teoria Feminista do Direito .......................................................43

Angela P. Harris, Tradução de Camilla de Magalhães Gomes e Ísis Aparecida Conceição

Políticas da morte: Covid-19 E Os Labirintos da Cidade Negra ........................................75

Ana Flauzina e Thula Pires

QUem PARIU AMÉFrica?: TRABALHO DOMÉSTICO, CONSTITUCIONALISMO E MEMÓRIA EM PRETUGUÊS

Juliana Araújo Lopes

O Lixo Vai Falar: Racismo, Sexismo e Invisibilidades do Sujeito Negro nas Narrativas de Direitos Humanos

Ciani Sueli das Neves

DiREITOS HUMANOS, DECOLONIALIDADE E FEMINISMO DECOLONIAL: FERRAMENTAS TEÓRICAS PARA A COMPREENSÃO DE RAÇA E GÊNERO NOS LOCAIS DE SUBALTERNIDADE

Rute Passos, Letícia Rocha Santos e Fran Espinoza

Direito, RAÇA E GÊNERO: ELEMENTOS PARA A CONSTRUÇÃo DE UMA TEORIA FEMINISTA DO DIREITO ADEQUADA AO FEMINISMO NEGRO

Mário Lúcio Garcez Calil e Debora Markman

"NeGras VAdiAs": A CRIMINALIZAÇÃo Do CORPO NEGRO QUE OUSA PROTESTAR.

Soraia da Rosa Mendes e Bruno Amaral Machado

A experiênCia do Abaetê Criolo como aÇão de enfrentamento a desigualdades de GÊNERO E RAÇA: UMA ANÁLISE DE DISCURSO SOBRE INTERSECCIONALIDADE

E FEMINISMO NEGRO

David Oliveira e Thalita Terto Costa 
ENTRE A AUSÊNCIA E O EXCESSO: A ATUAÇÃo DO ESTADO SOBRE CORPOS DISSIDENTES 230 Dayane do Carmo Barretos, Klelia Canabrava Aleixo e Vanessa de Sousa Soares

SILÊNCIOS E MITOS NUMA PERSPECTIVA INTERSECCIONAL: DO CONTROLE INFORMAL DE CORPOS AO CONTROLE PENAL DE MULHERES NEGRAS ......................................................248 Elaine Pimentel e Nathália Wanderley

Ministério Público e domínio Racial: poucas ilhas negras EM UM ARQuipélago nãoNEGRO 267

Saulo Murilo de Oliveira Mattos

Políticas públicas Para a ARTiCulaÇão de GÊNERo E RAÇA: MEIOS PARA GARANTir A REPRESENTATIVIDADE POLÍtiCA E JURÍDiCA DA MULHER NEGRA NO BRASIL 296 Mariana Dionísio de Andrade e Eduardo Régis Girão de Castro Pinto

Parte Específica: Incidências Concretas.......................................................... 317

REIMAGING THE POLICING OF GENDER VIOLENCE: LESSONS FROM WOMEN'S POLICE STATIONS IN Brasil AND ArgENTINA............................................................................................ 319 Kerry Carrington, Melissa Bull, Gisella Lopes Gomes Pinto Ferreira e María Victoria Puyol

NECROBIOPOLIÍtica DE GÊNERo No BRASIL CONTEMPORÂNEO: O FEMINICÍDIO EM TEMPOS DE FASCISMO SOCIAL 340 Maiquel Ângelo Dezordi Wermuth e Joice Graciele Nielsson

ViolÊNCIA CONTRA MULHERES QUILOMBOLAS: UMA REFLEXÃo SOBRE A APLICAÇÃo DE UMA PERSPECTIVA INTERSECCIONAL À LUZ DA IDEIA DE CONTRAPÚBLICOS SUBALTERNOS DELINEADA POR FRASER..... 360 Maria Eugenia Bunchaft, Leonardo Rabelo de Matos Silva e Gustavo Proença da Silva Mendonça

Políticas públicas de PREVEnÇÃo aO Feminicídio E INTERSECCIONALIDAdes . 384 Thiago Pierobom de Ávila, Marcela Novais Medeiros, Cátia Betânia Chagas, Elaine Novaes Vieira, Thais Quezado Soares Magalhães e Andrea Simoni de Zappa Passeto

DiREITO DE VIVER SEM VIOLÊNCIA: PROTEÇÃO E DESAFIOS DOS DIREITOS DAS MULHERES indígenas no Sistema InTERAmericano de Direitos Humanos Julia Natália Araújo Santos e Felipe Rodolfo de Carvalho

ANÁlise de GÊNERo E DE CRUZAMENTOS INTERSECCIONAIS DE UM PROGRAMA PARA AUTORES DE VIOLÊNCIA DOMÉSTICA CONTRA AS MULHERES

Mariana Fernandes Távora, Dália Costa, Camilla de Magalhães Gomes e Adriano Beiras

Controle PENAL dA LOUCURA E DO GÊNERO: REFLEXÕES INTERSECCIONAIS SOBRE MULHERES EgRESSAS DA MEdidA DE SEgurANÇA No Rio DE JANEIRO. .468 Bruna Martins Costa e Luciana Boiteux 
ONDE ESTÃo NOSSOS DIREITOS? O CAMPO FEMINISTA DE GÊNERO BORDADO PELAS MULHERES ATINGIDAS POR BARRAGENS

Tchenna Fernandes Maso e Tchella Fernandes Maso

Os SEGREDOS EPISTÊMICOS DO DIREITO DO TRABALHO.

Flávia Souza Máximo Pereira e Pedro Augusto Gravatá Nicoli

Reforma trabalhista e desigualdade de GÊNERo no Brasil: uMa PERSPECTIVA JuRÍdicA E ECONÔMICA

Natalia Branco Lopes Krawczun, Magno Rogério Gomes e Solange de Cassia Inforzato de Souza

A COLONIALIDADE DO PODER NA PERSPECTIVA DA INTERSECCIONALIDADE DE RAÇA E GÊNERO: ANÁLISE DO CASO DAS EMPREGADAS DOMÉSTICAS NO BRASIL .565

Daphne de Emílio Circunde Vieira Andrade e Maria Cecília Máximo Teodoro

COMPETIÇÃO POLÍTICA E DESIGUALDADES DE GÊNERO NAS ELEIÇÕES PARA ASSEMBLEIAS ESTADUAIS EM 2018

Lígia Fabris Campos, Décio Vieira da Rocha, Leandro Molhano Ribeiro e Vitor Peixoto

DisCrit: os LIMITES DA INTERSECCIONALIDADE PARA PENSAR SOBRE A PESSOA NEGRA COM DEFICIÊNCIA

Philippe Oliveira de Almeida e Luana Adriano Araújo

SeÇão III: Temais GeraIS

La Corte Interamericana de Derechos Humanos. Hermenéutica del derecho al MEDIO AMBIENTE SANO, A LA IDENTIDAD CULTURAL Y A LA CONSULTA, A LA LUZ DE LA SENTENCIA “Lhaka Honhat (nUestra tierra) vs. Argentina” (2020)

Juan Jorge Faundes Peñafiel, Cristobal Carmona Caldera e Pedro Pablo Silva Sánchez

LA RESPUESTA INSTITUCIONAL FRENTE A LA TRATA DE PERSONAS EN EL ESTADO DE CHIHUAHUA.

UN ANÁLISIS DE POLÍTICA PÚBLICA .676 Martha Aurelia Dena Ornelas

Comunidades quilombolas, RaCismo e ideologia no discurso de JAIr Bolsonaro: estudo CRÍTICO DOS DISCURSOS POLÍTICO E JUDICIAL 700 Ricardo de Macedo Menna Barreto e Helena Mascarenhas Ferraz

O Princípio Geral da Boa Administração no Código do Procedimento Administrativo Português. Pistas de inVestigação. 724 Ana Melro 


\title{
Comunidades quilombolas, racismo e ideologia no discurso de Jair Bolsonaro: estudo crítico dos discursos político e judicial*
}

\author{
Quilombolas communities, racism and \\ ideology in the speech of Jair Bolsonaro: \\ critical study of political and judicial discourse
}

Ricardo de Macedo Menna Barreto**

Helena Mascarenhas Ferraz***

\section{Resumo}

O presente artigo tem como objetivo analisar, criticamente, o discurso proferido no dia 03 de abril de 2017, pelo então deputado federal e pré-candidato à presidência da república, Jair Messias Bolsonaro, no Clube Hebraica Rio. Nesta ocasião, ficou evidenciada a visão estereotipada e preconceituosa de Bolsonaro, especialmente no que diz respeito à comunidade quilombola. Busca-se, assim, desvelar o alto teor ideológico contido nesse discurso, bem como o abuso de poder discursivo nele existente. Com efeito, a dimensão ideológica do discurso de Bolsonaro pode ser percebida pela utilização de um recurso típico da organização do discurso racista: a estratégia da autoapresentação positiva e outroapresentação negativa. Para desvelar a dimensão ideológica e de abuso de poder do discurso de Bolsonaro, nos serviremos dos Estudos Críticos do Discurso (ECD) de Teun A. van Dijk, os quais têm permitido interessante atualização da Crítica do Direito. Tal perspectiva teórica permitirá evidenciar, também, certos aspectos do discurso judicial, o qual, na ocasião, instrumentalizou o instituto jurídico da imunidade parlamentar para isentar Bolsonaro da responsabilidade civil pelos prejuízos ocasionados àquela minoria social. Buscar-se-á evidenciar, assim, não apenas a ideologia presente no discurso político de Bolsonaro, mas também a ideologia existente no Judiciário brasileiro e os dispositivos inibidores de eventuais resistências à sua dominação. Quanto à metodologia, o presente estudo crítico-linguístico dos discursos político e judicial, de caráter exploratório, combina aspectos teórico-metodológicos com aspectos empírico-sociais, utilizando pesquisa bibliográfica como instrumento de investigação.

Palavras-chave: Estudos Críticos do Discurso. Racismo. Ideologia. Direito. Política. sos de Licenciatura em Direito e nos Mestrados em Direito da Universidade do Minho, Portugal. Investigador Colaborador do JusGov (Centro de Investigação em Justiça e Governação) e do JusLab (Laboratório de Justiça) da Escola de Direito da Universidade do Minho, Portugal. E-mail: ricardo.mennabarreto@gmail.com.

\section{Abstract}

The purpose of this article is to critically analyze the discourse delivered on April 3, 2017, by the then federal deputy and pre-candidate for president of the republic, Jair Messias Bolsonaro, at Clube Hebraica Rio. On this occa- 
sion, Bolsonaro's stereotyped and prejudiced view was evidenced, especially in relation to the quilombola community. Thus, it seeks to unveil the high ideological content contained in this discourse, as well as the abuse of discursive power in it. Indeed, the ideological dimension of Bolsonaro's discourse can be perceived through the use of a typical resource of the organization of racist speech: the strategy of positive self-presentation and other-negative presentation. To unveil the ideological and abuse of power dimension of Bolsonaro's discourse, we will use Teun A. van Dijk's Critical Discourse Studies (CDS), which have allowed an interesting update of the Critique of Law. Such a theoretical perspective will also make it possible to highlight certain aspects of the judicial discourse, which, at the time, instrumentalized the legal institute of parliamentary immunity to exempt Bolsonaro from civil liability for the losses caused to that social minority. Thus, it will be sought to highlight not only the ideology present in Bolsonaro's political discourse, but also that ideology existing in the Brazilian Judiciary and the inhibiting devices of any resistance to his domination. As for the methodology, the present critical-linguistic study of political and judicial discourses, of an exploratory nature, combines theoretical and methodological aspects with empirical and social aspects, using bibliographic research as a research tool.

Key-words: Critical Discourse Studies. Racism. Ideology. Law. Politics.

\section{Introdução}

A esfera política é um campo de disputa de poder por excelência. É o espaço privilegiado de propagação de ideias, onde os discursos públicos dos atores políticos ganham ampla repercussão. E, no contexto particular do Estado de Direito, tais discursos são protegidos por institutos jurídicos. Faz-se isso, a princípio, com o objetivo de manter a democracia, por meio da pluralidade de ideias e da livre manifestação do pensamento.

Todavia, ainda que o poder seja comumente relacionado à ideia de Estado, ele está presente e permeia toda a sociedade, nas mais diversas dimensões. Nesse sentido, não podemos ignorar que todo discurso sempre traz, em seu bojo, uma ideologia, embora pareça neutro e o sujeito difusor o tente reproduzir "acriticamente". Assim, analisar quem profere, ou os destinatários do discurso, é algo que não pode ser feito isoladamente, mas apenas contextual e socialmente. A análise dos mecanismos de produção do discurso e o seu contexto é, por conseguinte, de fundamental importância para um estudo crítico do discurso que se pretenda capaz de revelar a ideologia, o poder e a dominação social.

Para Michel Foucault ${ }^{1}$, “(...) em toda sociedade a produção do discurso é ao mesmo tempo controlada, selecionada, organizada e redistribuída por certo número de procedimentos que têm por função conjurar seus poderes e perigos, dominar seu acontecimento aleatório, esquivar sua pesada e temível materialidade". Nesse sentido, a ideologia contida no discurso pressupõe a existência do poder que se articula entre as camadas de diferentes tecidos sociais, atravessando instituições e estruturas - ao mesmo tempo em que forja significados e representações da realidade por meio de diferentes discursos, como o científico, o midiático, o político ou o jurídico — com o objetivo de impor e/ou manter a dominação.

Desse modo, detectar a ideologia oculta nos discursos político e judicial relativos à palestra de Jair Bolsonaro no Clube Hebraica Rio, evidenciando o poder que os direciona e a dominação que provocam, são alguns dos objetivos pretendidos com o presente artigo. Para tanto, utilizaremos, em nossa análise, os Estudos Críticos do Discurso (EDC), proposta do linguista holandês Teun A. van Dijk². Já foi salientada

FOUCAULT, Michel. A Ordem do Discurso. Aula inaugural do Collège de France pronunciada em 2 de dezembro de 1970. São Paulo: Edições Loyola, 2014, pp. 08-09.

2 DIJK, Teun A. van. Structures of Discourse and Structures of Power. In: ANDERSON, J. A. (Ed.). Communication Yearbook 12 , Newbury Park, CA: Sage, 1989. DIJK, Teun A. van. Discurso e Poder. Org. Hoffnagel, Judith e Falcone, Karina. $2^{\mathrm{a}}$ ed. $1^{\mathrm{a}}$ reimpressão. São Paulo: Contexto, 2012. 
a pertinência dos ECD de van Dijk para uma atualização da Crítica do Direito, dado existir uma espécie de equivalência funcional metalinguística entre os ECD e a Crítica do Direito. Em outras palavras, ambos buscam, cada qual em seu respectivo campo, realizar uma crítica social, fruto de certa inconformidade com o inscrito e o instituído na sociedade contemporânea. Nesse aspecto, o presente estudo se situa no âmbito da Crítica do Direito, aqui atualizada no sentido de se estabelecer uma "Crítica Linguística do Direito" ${ }^{3}$.

Quanto à metodologia, o presente estudo crítico-linguístico dos discursos político e judicial, de caráter exploratório, combina aspectos teórico-metodológicos com aspectos empírico-sociais, permitindo uma reflexão jurídica condizente com as configurações da sociedade atual. Quanto ao instrumento de investigação, utiliza-se a pesquisa bibliográfica.

Por fim, vale observar o modo como o presente artigo se encontra estruturado. Para além da presente introdução (1), dividimos o presente artigo em três grandes seções, fechando-o com as conclusões (5). $\mathrm{Na}$ segunda seção, intitulada "2. A Palestra de Jair Bolsonaro no Clube Judaico Hebraica Rio: contextualização fática e judicial", buscamos descrever o contexto do discurso de Bolsonaro, com ênfase no trecho de suas críticas aos quilombolas, além de contextualizar a repercussão judicial da fala de Bolsonaro. Por conseguinte, em "3. Comunidades quilombolas no Brasil: passado e presente", buscamos realizar breve análise histórico-social das comunidades quilombolas, abordando, igualmente, os aspectos jurídicos que envolvem tais comunidades. Em um quarto momento, intitulado "4. Estudos Críticos do Discurso: ideologia, poder e racismo", apresentamos algumas noções basilares dos ECD de van Dijk, visando, especificamente, em "4.1. Autoapresentação positiva, outroapresentação negativa e o racismo recreativo de Bolsonaro", abordar uma estratégia bastante comum nos discursos racistas, percebida na fala de Bolsonaro. Fecharemos a quarta seção com “4.2. Estudo Crítico do Discurso Judicial”, no qual desenvolvemos um estudo crítico do discurso judicial, em especial do Acórdão (emanado do Tribunal Regional da $2^{a}$ Região) que teve como relator o Desembargador Federal Marcelo Pereira da Silva.

\section{A palestra de Jair Bolsonaro no Clube Judaico Hebraica Rio: contextualização fática e judicial}

Após um ano de incertezas no cenário político brasileiro, 2017 começou com a especulação da opinião pública sobre nomes de possíveis candidatos à presidência da república nas eleições que ocorreriam em 2018. Jair Messias Bolsonaro, então deputado federal do Estado do Rio de Janeiro, foi um dos nomes mais cotados para a disputa. Sua pré-candidatura foi apresentada publicamente já em março de $2016^{4}$.

Porém, ao longo de sua carreira política, diversas foram as manifestações públicas preconceituosas e

\footnotetext{
MENNA BARRETO, Ricardo de Macedo. Direito, Discurso e Poder: os Media e a Decisão Judicial. Tese de Doutoramento em Ciências Jurídicas Gerais. Escola de Direito, Universidade do Minho, 2019.

4 Nesse sentido, reportagem do Jornal Folha de São Paulo acerca da divulgação da pré-candidatura à presidência em junho de 2016: FOLHA DE SÃO PAULO. "Pré-candidato, Bolsonaro tenta criar a 'extrema direita light". Disponível em: <https://www1.folha. uol.com.br/poder/2016/06/1779759-pre-candidato-bolsonaro-tenta-criar-a-extrema-direita-light.shtml >. Acesso em 27 de março de 2020 .
} 
discriminatórias contra minorias sociais, prioritariamente, mulheres ${ }^{5}$, população LGBT ${ }^{6}$ e negros ${ }^{7}$. Observe-se, igualmente, o apoio explícito de Bolsonaro à ditadura militar ${ }^{8}$, à tortura ${ }^{9}$, ao armamento da população em geral etc. Um exemplo desse tipo de discurso ocorreu no dia 03 de abril de 2017, para uma plateia de, aproximadamente, trezentos convidados no Clube Judaico Hebraica Rio, na qual Bolsonaro expôs, enquanto pré-candidato à Presidência da República, sua percepção político-ideológica acerca das estratégias de administração pública adotadas, em âmbito nacional e internacional, pelo Poder Executivo, nomeadamente, pelos mandatos dos representantes do Partido dos Trabalhadores (PT), Luiz Inácio Lula da Silva e Dilma Rousseff.

$\mathrm{Na}$ ocasião, a polarização política, já nítida na sociedade brasileira de forma geral, foi evidenciada também para a comunidade judaica. A priori, o interesse pela palestra foi aventado pela sede paulista do clube que, no entanto, não concretizou o convite após manifestação de seus membros pugnando pelo cancelamento, o que foi feito por meio de um abaixo-assinado que contou com mais de 2.700 assinaturas ${ }^{10}$. Cientes do cancelamento em São Paulo, membros do Clube Hebraica Rio ${ }^{11}$, alinhados à ideologia política da extrema-direita, formalizaram o convite ao pré-candidato e organizaram o evento, em oposição a outra parte da comunidade judaica - inclusive, mencionada de forma vexatória durante a palestra, que, à porta do clube carioca, manifestou sua insatisfação ${ }^{12}$. A palestra foi gravada e o vídeo ${ }^{13}$ posteriormente disponibilizado em redes sociais por grupos de apoiadores. No dia seguinte, a Confederação Israelita do Brasil - CONIB emitiu nota ${ }^{14}$ por meio da qual se posicionou da seguinte forma:

\footnotetext{
5 Durante entrevista concedida em 2008 ao Jornal da RedeTV, Bolsonaro discutiu com a também deputada federal, Maria do Rosário (PT), dizendo-lhe que não a estupraria porque ela não merecia. Vídeo disponível em: < https://www.youtube.com/embed/ atKHN_irOsQ? rel=0>. Acesso em: 27 de março de 2020.

6 Os exemplos de discursos discriminatórios contra a comunidade LGBT são inúmeros. Em razão disso, mencionaremos apenas dois. Em 2008, na Tribuna da Câmara, Bolsonaro pronuncia-se sobre indicação de Eleonora Menicucci para assumir à Secretaria de Políticas para Mulheres no governo Dilma Rousseff, desqualificando-a por relacionar-se com homens e mulheres e a chamando de "sapatão". Vídeo disponível em: <https://www.youtube.com/embed/Do6nXV59ZzE?rel=0>, acesso em 27 de março de 2020. Outro exemplo é a entrevista, concedida em 2014, ao Jornal espanhol El País, momento em que Bolsonaro afirma que a homossexualidade é fruto "da influência de amigos e da televisão, ou por consumo de drogas". Cfe. "Os gays não são semideuses. A maioria é fruto do consumo de drogas". Disponível em: < https://brasil.elpais.com/brasil/2014/02/14/politica/1392402426_093148.html>. Acesso em: 27 de março de 2020.

Em entrevista concedida ao Programa CQC da BandTV, em 2011, Bolsonaro responde à pergunta da cantora Preta Gil, sobre "o que você faria se seu filho se apaixonasse por uma negra?", da seguinte forma: "Preta, eu não vou discutir promiscuidade com quem quer que seja. Eu não corro esse risco. Meus filhos foram muito bem educados e não viveram em ambiente como lamentavelmente é o teu." Vídeo disponível por meio do link: <https://www.youtube.com/embed/lkZv3iyZdkA?rel=0>. Acesso em 27 de março de 2020.

8 Durante a sessão que decidiu o processo de impeachment da presidenta Dilma Rousseff, em 2016, ao declarar seu voto favorável, Bolsonaro prestou homenagem ao coronel Carlos Brilhante Ustra, conhecido torturador da época em que o país vivia sob o regime de ditadura militar. Tal episódio pode ser verificado no vídeo disponível em: $<$ https://www.youtube.com/watch?v=xiAZn7bUC8A $>$. Acesso em 25 de março de 2020.

9 Em entrevista concedida a um Jornal da TV Bandeirantes em 1999, Bolsonaro defendeu abertamente a tortura e a morte de brasileiros, conforme pode ser verificado no vídeo disponível em: <https://www.youtube.com/watch?v=ihvl497x37c > Acesso em 25 de março de 2020.

10 Cfe. CONGRESSO EM FOCO. "Reação da comunidade judaica leva a suspensão da palestra de Bolsonaro no Clube Hebraica". 28 de fevereiro de 2017. Disponível em: <https://congressoemfoco.uol.com.br/especial/noticias/reacao-da-comunidade-judaica-levaa-suspensao-palestra-de-bolsonaro-no-clube-hebraica/> Acesso em 17 de maio de 2020.

11 O Clube Hebraica Rio não tem a mesma atuação na cidade que a sede homônima paulista, sendo apenas local de eventos para empresas privadas mediante pagamento. Cfe. GHERMAN, Michel e KLEIN, Misha. Entre 'conversos' e 'desconversos': o caso da influência da Nova Direita Brasileira sobre a comunidade judaica do Rio de Janeiro. In: Revista de Estudios Sociales del Estado, V. 5 n 9 , jan-jun 2019, pp. 101-123. Disponível em: < http://www.estudiossocialesdelestado.org/index.php/ese/article/view/173>. Acesso em 18 de maio de 2020, p. 116.

12 Parte da comunidade judaica no Rio de Janeiro tem profunda identificação com setores conservadores tanto da igreja católica, quanto das igrejas evangélicas neopentecostais (o prefeito da cidade do Rio de Janeiro é pastor da Igreja Universal do Reino de Deus), alinham-se ideologicamente com a extrema-direita brasileira e foram os responsáveis pela organização do evento. GHERMAN, Michel e KLEIN, Misha. Entre 'conversos' e 'desconversos': o caso da influência da Nova Direita Brasileira sobre a comunidade judaica do Rio de Janeiro. In: Revista de Estudios Sociales del Estado, V. 5 n 9, jan-jun 2019, pp. 101-123. Disponível em: <http:// www.estudiossocialesdelestado.org/index.php/ese/article/view/173>. Acesso em 18 de maio de 2020, p. 117.

13 Íntegra da palestra proferida no Clube Hebraica Rio em 03 de março de 2017. Disponível em: <https://www.youtube.com/ watch?v=LPj4KyLw8Wc >. Acesso em: 15 de março de 2020.

14 Íntegra da nota oficial da Confederação Israelita do Brasil disponível no link: <https://www.conib.org.br/nota-sobre-a-pale-
} 
a Conib apoia o debate político e acha que ele é sempre necessário. Ainda mais nesse momento de desdobramentos dramáticos da política nacional. Defendemos, porém, que esse debate tenha critérios e seja pautado, sempre, pelo equilíbrio e pela pluralidade. Nossa comunidade abriga uma grande diversidade de pensamento, e os dirigentes comunitários precisam ter isso claro para bem cumprirem seu papel. A comunidade judaica defende, de forma intransigente, os valores da democracia e da tolerância e o respeito absoluto a todas as minorias.

Desse modo, o vídeo se tornou assunto da mídia ${ }^{15}$, projetando, nacionalmente, os discursos proferidos em tom jocoso contra minorias sociais, sob risos e aplausos do público judeu extremista e, tal qual o palestrante, intolerante às diferenças.

Não obstante boa parte do discurso proferido na referida palestra ser passível de um estudo crítico-discursivo, a grande quantidade de alvos para os quais Bolsonaro direcionou frases preconceituosas e discriminatórias inviabiliza o feito em apenas um artigo. Nesse sentido, daremos ênfase, apenas, ao trecho do discurso (abaixo reproduzido) que faz referência à comunidade quilombola, o qual rendeu à Bolsonaro dois processos judiciais ${ }^{16}$ :

aqui apenas ó, são as reservas indigenas no Brasil né, onde têm uma reserva indigena, tem uma riqueza embaixo dela. Temos que mudar isso daí! Mas nós não temos hoje em dia mais autonomia para mudar isso daí. Entregou-se tanto nossa nação que chegamos a esse ponto. Mas dá pra mudar o nosso país! Isso aqui é só reserva indigena, tá faltando quilombolas... é outra brincadeira. Eu fui num quilombola em Eldorado Paulista... olha, o afrodescendente mais leve lá, pesava sete arrobas... não fazem nada! Eu acho que nem pra procriadores servem mais... mais de um bilhão de reais por ano gastado com eles. Recebem cesta básica e mais material... implemento agrícola e aí você vai em Eldorado Paulista você compra, arame, de arame de farpado, você compra enxada, pá, picareta, por metade do preço! Vendido em outra cidade vizinha, porquê? Eles revendem tudo baratinho lá, não querem nada com nada! Esse quilombola era a montante e a jusante do rio Ribeira de Igua, depois foram a jusantes! Pior ainda afrodescendente ameaçando matar afrodescendente! Porque algumas famílias, requereram e foi concedido e outras famílias de afrodescendentes que tem terra lá tão fora do processo. Olha que ponto nós chegamos. O governo federal estimulando... a luta de classes.

É, portanto, esse trecho em particular da fala de Bolsonaro que será retomado para um estudo crítico mais à frente. Quanto ao contexto judicial, em 10 de abril de 2017, foi ajuizada a Ação Civil Pública (Processo n. ${ }^{\circ}$ 0101298-70.2017.4.02.5101) que tramitou perante a 26 ${ }^{a}$ Vara Federal da Seção Judiciária do Rio de Janeiro, na qual Jair Bolsonaro foi condenado em primeira instância pela Juíza Frana Elizabeth Mendes ao pagamento de $\mathrm{R} \$ 50.000,00$ à título de danos morais coletivos, valor que seria revertido ao Fundo Federal de Defesa dos Direitos Difusos. Em segunda instância, no entanto, essa decisão foi reformada pelo Desembargador Relator, Marcelo Pereira da Silva, que cobriu Bolsonaro com o manto da imunidade parlamentar, isentando-o, assim, de qualquer reparação na esfera cível.

Por outro lado, em âmbito criminal, tramitou perante o Supremo Tribunal Federal (STF) o Inquérito n. ${ }^{\circ}$ 4.694/Distrito Federal, por meio do qual o MPF encaminhou denúncia em desfavor de Bolsonaro, como incurso pelo crime definido no caput do artigo 20 da Lei 7.716 de $1989^{17}$. Tal denúncia, contudo, foi rejeitada pelos ministros julgadores ao considerarem que não houve a prática do crime, em razão da ausência

stra-de-jair-bolsonaro-na-hebraica-rio/> Acesso em: 17 de maio de 2020.

15 FOLHA DE SÃO PAULO. "Entidade judaica condena fala de Bolsonaro em clube". Disponível em: < http://www1.folha. uol.com.br/poder/2017/04/1873049-entidade-judaica-condena-fala-de-bolsonaro-em-clube.shtml>. Reportagem do Jornal O GLOBO disponível em: < https://oglobo.globo.com/brasil/grupo-quilombola-faz-representacao-contra-jair-bolsonaro-por-racismo-21177099>. Reportagem do portal CONJUR (Consultor Jurídico). Disponível em: < https://www.conjur.com.br/2017-abr-10/ mpf-move-acao-bolsonaro-ataques-negros-quilombolas $>$. Todos acessados em 27 de março de 2020.

16 Íntegra da Representação apresentada pelo CONAQ e Terra de Direitos ao MPF disponível em: < https://terradedireitos.org. br/wp-content/uploads/2017/04/repre.-Bolsonaro.pdf>.

17 Art. 20. Praticar, induzir ou incitar a discriminação ou preconceito de raça, cor, etnia, religião ou procedência nacional. (Redação dada pela Lei n. ${ }^{\circ} 9.459$, de 15/05/97).

Pena: reclusão de um a três anos e multa.(Redação dada pela Lei n. ${ }^{\circ}$ 9.459, de 15/05/97). Cfe. BRASIL, Presidência da República. Casa Civil. Subchefia para Assuntos Jurídicos. Lei N. ${ }^{0}$ 7.716, de 5 de janeiro de 1989. Disponível em: <http://www.planalto.gov.br/ ccivil_03/leis/17716.htm>. Acesso em: 16 de março de 2020 . 
de um dos elementos indispensáveis a configuração do ato discriminatório, nomeadamente, a finalidade. Entendeu-se, além disso, que a conduta estava abrangida pela imunidade parlamentar ${ }^{18}$.

A seguir, realizaremos breve contextualização histórica das comunidades quilombolas no Brasil, visando estabelecer, deste modo, uma compreensão histórico-social teoricamente informada acerca da dimensão ideológica do discurso de Bolsonaro.

\section{Comunidades quilombolas no Brasil: passado e presente}

É importante percebemos exatamente de quem se está a falar quando se refere a comunidades quilombolas. Nesse sentido, encontramos diversas questões, que buscaremos responder ao longo desta seção, tais como: qual a abordagem legal dada aos quilombos no período colonial e imperial? Como se deu o processo de invisibilização dessas comunidades após a abolição formal da escravatura? Sob qual perspectiva operou-se o ressurgimento dos quilombos no ordenamento jurídico brasileiro a partir da promulgação da Constituição Federal de 1988? E, finalmente, por qual motivo uma ínfima parcela das terras quilombolas foi objeto de certificação pelo poder público?

A engrenagem do sistema colonial no Brasil dependia, fundamentalmente, da mão-de-obra escravizada para seu funcionamento e reprodução. Desde o início da colonização portuguesa ${ }^{19} \mathrm{e}$, concomitantemente, da importação de africanos escravizados, houve resistência ao sistema que reduzia essa população à condição de semovente, na categoria de patrimônio privado. Com efeito, é a insurgência radical negra à desumanização violenta de suas existências ${ }^{20}$ que dá origem aos quilombos.

A primeira expressão legal acerca dos quilombos no regime colonial ocorre em 1722, no Regimento dos Capitães-do-Mato de Dom Lourenço de Almeida ${ }^{21}$, com vistas à repressão da formação dessas comunidades, no mesmo sentido em que é empregada pelo Conselho Ultramarino em $1740^{22}$.

O tratamento legal não foi muito diferente no período histórico subsequente. Porém, ao longo do regime imperial, o aumento da resistência, a pressão internacional exercida sobre o Império brasileiro (tratado internacional de 22 de janeiro de 1815), especialmente, pelo Reino Unido (tratado internacional firmado em 1826 e a Lei Bill Aberdeen em 1845) e o fortalecimento, em âmbito nacional, do movimento abolicionista ${ }^{23}$,

\footnotetext{
18 Por questões de delimitação e espaço, nosso estudo crítico do discurso judicial será dirigido apenas ao Acórdão do Tribunal Regional da $2^{\mathrm{a}}$ Região (BRASIL. Poder Judiciário. Tribunal Regional da $2^{\mathrm{a}}$ Região. Apelação Cível. Turma Especial III. Administrativo e Cível. N. ${ }^{\circ}$ CNJ: 0101298-70.2017.4.02.5101 [2017.51.01.101298-3]. Relator: Desembargador Federal Marcelo Pereira da Silva. Apelante: Ministério Público Federal e outros. Procurador: Procurador Regional da República e outros. Apelado: os mesmos. Origem: 26a Vara Federal do Rio de Janeiro [01012987020174025101]. Disponível em: <https://www.migalhas.com.br/arquivos/2018/9/ art20180925-04.pdf>. Acesso em: 12 de abril de 2020). Em outro estudo, já iniciado, nos dedicaremos à análise do Acórdão do STF (BRASIL. Supremo Tribunal Federal. Primeira Turma. Inquérito No 4.694. Distrito Federal. Relator: Ministro Marco Aurélio. Autor: Ministério Público Federal. Proc.(a/s)(es): Procurador-Geral da República. Invest.(a/s): Jair Messias Bolsonaro. Adv. (a/s): Antônio Sérgio Altieri de Moraes Pitombo e outros (a/s). Data: 11/09/2018. Disponível em: < https://stf.jusbrasil.com.br/jurisprudencia/768164396/inquerito-inq-4694-df-distrito-federal-0016317-5720181000000/inteiro-teor-768164398?ref=serp>. Acesso em: 12 de abril de 2020), cujos resultados ficam condicionados a uma publicação futura.

19 NASCIMENTO, Abdias do. O Genocídio do Negro Brasileiro: processo de um racismo mascarado. $3^{\mathrm{a}}$ ed. São Paulo: Perspectiva, 2016 , p. 72. 20 SOUZA, Barbara Oliveira. Aquilombar-se: Panorama Histórico, Identitário e Político do Movimento Quilombola Brasileiro. Brasília, 2008 , p. 26. 21 [\$3] Pellos negros que forem prezos em quilombos formados distantes de povoação onde estejão aSima de quatro negros, com Ranchos piloens, e modo de aly se conservarem, haveram por cada negro destes vinte outavas de ouro. Cfe. REGIMENTO DOS CAPITÃES DO MATO, 17/12/1722. In: Atlas Digital da América Lusa. Disponível em: <http://hs.unb.br/atlas/Regimento_dos_Capitães_do_mato,_17/12/1722>. Acesso em: 16 de março de 2020.

22 Conselho Ultramarino em 1740: (...) toda habitação de negros fugidos, que passem de cinco, em parte despovoada, ainda que não tenham ranchos levantados nem se achem pilões nele.

23 BIBLIOTECA NACIONAL DIGITAL. Disponível em: < https://bndigital.bn.gov.br/dossies/trafico-de-escravos-no-brasil/ acordos-internacionais-e-legislacao-sobre-escravidao>. Acesso em: 18 de março de 2020.
} 
culminou com a Lei Eusébio de Queiroz, de 04 de setembro de $1850^{24}$, a extinguir, definitivamente, a importação de africanos escravizados para o país.

Concomitantemente, diversos foram os incentivos do governo brasileiro para a imigração de pessoas brancas, especialmente, europeus ${ }^{25}$. A Lei de Terras de 18 de setembro de $1850^{26}$ aparece nesse contexto histórico. A regulamentação do acesso à terra tinha o objetivo de impedir a aquisição pelos imigrantes da propriedade por meio da posse contínua ou doações, já que a imigração tinha o fito de substituir a mão-de-obra escravizada nas lavouras ${ }^{27}$. A lei desencadeou uma intensa movimentação dos supostos donos, grileiros e posseiros, provocando a deslocação violenta de diversas comunidades quilombolas, historicamente, situadas em terras devolutas ${ }^{28}$.

Assim, percebe-se que as comunidades quilombolas, durante os regimes colonial e imperial, representavam a radicalização da resistência negra face à brutalidade do sistema escravagista, a engendrar a expressão mais nítida de uma possível ruptura da ordem social, econômica, ideológica e política vigente ${ }^{29}$.

Após a abolição formal da escravidão no Brasil em 1888, como em todo o período republicano, não existia, na legislação, nenhuma menção às comunidades quilombolas que estavam espalhadas por todo o território nacional ${ }^{30}$. A Lei Áurea concedeu liberdade formal aos negros escravizados, porém o Estado brasileiro não criou condições materiais para seu pleno exercício. Ao mesmo tempo, a sociedade brasileira e suas instituições, estruturadas a partir da ótica dicotômica racista do sistema colonial escravagista, recepcionou, de bom grado, normas sociais segregacionistas ${ }^{31}$, oriundas do direito consuetudinário, por meio das quais era defeso aos negros frequentar determinados locais, ter pleno acesso ao trabalho remunerado e à justiça, enfim, participar, ativamente, da vida em sociedade na qualidade de cidadãos.

Diferentemente dos EUA, que oficializaram a segregação racial na legislação, chamada Jim Crow, ou da África do Sul, com o regime de aparteid, no Brasil a segregação ocorreu por meio dos usos e costumes da época, da eficácia das normas sociais não institucionalizadas, embasadas em teorias pseudocientíficas racistas ${ }^{32}$, buscadas na Europa pela elite branca e intelectual brasileira.

Ao longo de 100 anos — desde o fim da escravidão até a promulgação da Constituição Federal de 1988 —, a comunidade quilombola foi literalmente apagada do ordenamento jurídico brasileiro e, em consequência, do imaginário coletivo nacional, pois, até aquele momento (da abolição), as leis se limitavam a coibir sua formação, sendo que, posteriormente, omitiu-se supondo sua extinção juntamente com a escravidão ${ }^{33}$.

A perspectiva pela qual os quilombos ressurgem na legislação pátria em 1988 é a de acesso a direitos. Nesse aspecto, manifestam-se na condição de minoria social, recebendo proteção normativa do Estado

\footnotetext{
24 Texto integral da Lei disponível em: <http://www.planalto.gov.br/ccivil_03/leis/lim/LIM581.htm>. Acesso em: 25 de março de 2020

25 HERNÁNDEZ, Tanya Katerí. A Inocência Racial, o Direito Costumeiro e a Nova Resposta dos Direitos Civis. Trad. de Ariovaldo Santos de Souza e Luciana Carvalho Fonseca. Salvador: EDUFBA, 2017, p. 23.

26 Texto integral da Lei disponível em: <http://www.planalto.gov.br/ccivil_03/LEIS/L0601-1850.htm>. Acesso em: 17 de março de 2020.

27 LIMA, Angela Bernadete. A imigração para o império do Brasil: um olhar sobre os discursos acerca dos imigrantes estrangeiros no século XIX. In: Revista Acadêmica Licenciadóacturas, Ivoti, v.5, n. 2, jul-dez de 2017, pp. 26-36. Disponível em: <http://www.ieduc. org.br/ojs/index.php/licenciaeacturas/article/download/155/130>. Acesso em: 29 de março de 2020.

28 SOUZA, Barbara Oliveira. Aquilombar-se: Panorama Histórico, Identitário e Político do Movimento Quilombola Brasileiro. Brasília, 2008 , p. 35.

29 SOUZA, Barbara Oliveira. Aquilombar-se: Panorama Histórico, Identitário e Político do Movimento Quilombola Brasileiro. Brasília, 2008, p. 26.

30 SOUZA, Barbara Oliveira. Aquilombar-se: Panorama Histórico, Identitário e Político do Movimento Quilombola Brasileiro. Brasília, 2008, p. 46.

31 HERNÁNDEZ, Tanya Katerí. A Inocência Racial, o Direito Costumeiro e a Nova Resposta dos Direitos Civis. Trad. de Ariovaldo Santos de Souza e Luciana Carvalho Fonseca. Salvador: EDUFBA, 2017, p. 21.

32 CARONE, Iray e BENTO, Maria Aparecida Silva (org.). Psicologia Social do Racismo: Estudos sobre branquetude e branqueamento no Brasil. 6a ed. Petrópolis: Vozes, 2014, p. 14.

33 SOUZA, Barbara Oliveira. Aquilombar-se: Panorama Histórico, Identitário e Político do Movimento Quilombola Brasileiro. Brasília, 2008, p. 77.
} 
brasileiro $^{34}$. A elaboração da $\mathrm{CF} / 88$ se deu em um contexto histórico de redemocratização política, após 21 anos de ditadura militar, e de redefinição das estruturas da sociedade. Nesse sentido, a nova carta política, chamada Constituição Cidadã, insere o Princípio da Igualdade Formal na concepção mais ampla de acesso igualitário aos direitos sociais, tão mitigados pelos governos autoritários precedentes, incluindo, nessa categoria, a regulamentação das terras dos remanescentes da comunidade quilombola (Artigo 68 dos Atos de Disposição Constitucional Transitória - ADCT).

Todavia, a constitucionalização ${ }^{35}$ do direito da comunidade quilombola à regulamentação de seu território não foi capaz de fomentar vontade política nos agentes públicos responsáveis pela implementação das disposições constitucionais programáticas. Até os dias atuais, é possível observar a articulação do poder público em favor dos interesses antagônicos aos direitos da comunidade quilombola, por meio da imposição de entraves à concessão da certificação e do excesso de burocracia ${ }^{36}$, além da falta de investimento público nos órgãos responsáveis ${ }^{37}$.

A prevalência dos interesses da iniciativa privada sobre o território quilombola se deve à representação que esse setor dispõe no Congresso Nacional, a exemplo dos evangélicos ${ }^{38}$. Assim, ao antecipar sua intenção de não cumprir o dispositivo constitucional e ferir o direito fundamental dos quilombolas caso fosse eleito, o então deputado federal e pré-candidato a presidente, Jair Bolsonaro, deixava nítida a direção do vento a guiar-lhe o rumo.

Na próxima seção, realizaremos uma abordagem crítico-discusiva da ideologia, do poder e do racismo para empreender, em seguida, um estudo crítico do discurso de Bolsonaro proferido no Clube Judaico Hebraica Rio em 2017, nomeadamente do trecho que faz menção à comunidade quilombola. Do mesmo modo, faremos crítica ao discurso judicial, o qual parece reforçar o racismo institucional ao contemplar a ideologia da democracia racial, por meio da qual se coloca a questão do preconceito e da discriminação racial na esfera do privado, como ofensa à honra pessoal, sem contemplar os sérios reflexos sociais da discriminação para a população negra, de forma geral, e para a comunidade quilombola, em particular.

\section{Estudos críticos do discurso: ideologia, poder e racismo}

Os Estudos Críticos do Discurso (ECD), propostos pelo linguista holandês Teun A. van Dijk, um dos principais expoentes mundiais da corrente linguística denominada Análise Crítica do Discurso (ACD), vem possibilitando significativa ampliação dos horizontes das reflexões jurídico-linguísticas, em especial da Crítica do Direito ${ }^{39}$. Nesse sentido, nos serviremos dos subsídios teóricos dos estudos crítico-discursivos de van Dijk para reflexão e estudo do discurso de Bolsonaro no Clube Hebraica Rio em 2017.

\footnotetext{
34 SOUZA, Barbara Oliveira. Aquilombar-se: Panorama Histórico, Identitário e Político do Movimento Quilombola Brasileiro. Brasília, 2008, p. 46.

35 BRASIL. EMI N. 58. Disponível em: <http://www.planalto.gov.br/ccivil_03/Exm/2003/EMI58-CCV-MINC-MDA-SEPPIR-03.htm>. Acesso em 27 de março de 2020.

36 NASCIMENTO, Germana Aguiar Ribeiro do, BATISTA, Mércia Rejane e Rangel e NASCIMENTO, Marilia Aguiar Ribeiro do. Panorama atual de proteção do direito à terra das comunidades quilombolas e desafios futuros. In: Interações, vol. 17, n.3, Campo Grande, jul-set de 2016, pp. 432-447. Disponível em: <http://dx.doi.org/10.20435/1984-042X-2016-v.17-n.3(07)>. Acesso em: 20 de março de 2020.

37 TERRA DE DIREITOS. “Orçamento para titulação de territórios quilombolas cai mais de 97\% em cinco anos". Disponível em: < https://terradedireitos.org.br/noticias/noticias/orcamento-para-titulacao-de-territorios-quilombolas-cai-mais-de-97-em-cinco-anos/22824>. Acesso em: 27 de março de 2020.

38 Matéria divulgada no site do Senado a ilustrar a articulação das bancadas no Congresso Nacional. SENADO FEDERAL. "Deputados das bancadas da 'bala, boi e Bíblia' atuam juntos em defesa de interesses próprios e aumentam poder do presidente da Câmara". Disponível. <https://www2.senado.leg.br/bdsf/bitstream/handle/id/509963/noticia.html?sequence=1>. Acesso em: 20 de março de 2020.

39 Cfe. proposto por MENNA BARRETO, Ricardo de Macedo. Direito, Discurso e Poder: os Media e a Decisão Judicial. Tese de Doutoramento em Ciências Jurídicas Gerais. Escola de Direito, Universidade do Minho, 2019.
} 
Desde a perspectiva dos ECD, podemos perceber que o poder, atualmente, não se dá mais em termos de classe, ou mesmo de controle sobre os meios materiais de produção. Hoje o poder é exercido, sobretudo, pelo controle da "mente das massas", e este requer o controle sobre o discurso público em todas as suas dimensões semióticas ${ }^{40}$. Pode-se afirmar, com Roger Fowler, que o "poder é a capacidade das pessoas e das instituições de controlar o comportamento e a vida material dos outros" ${ }^{\prime 1}$, em função disso, comumente, o poder aparece relacionado à ideia de Estado.

O poder parte da observação das relações de diferença, ou, melhor dizendo, dos efeitos das diferenças no plano das estruturas sociais. Em concordância com essa perspectiva, devemos considerar a existência de uma certa "unidade da linguagem" com questões sociais, o que garante que a linguagem sempre estará, de algum modo, entrelaçada ao poder social. Significa afirmar que a linguagem indexa e expressa o poder, além de sempre estar envolvida onde houver uma contenção, ou mesmo um desafio, ao poder ${ }^{42}$.

Nesse sentido, pode-se dizer que as formas linguísticas são usadas em várias expressões e manipulações de poder. Todavia, este não se pronuncia somente pelas formas gramaticais constitutivas do texto, mas, para além disso, pelo controle exercido por uma pessoa de uma dada posição social e pelo gênero atribuído a um determinado texto ${ }^{43}$. Tal ideia pode ser percebida no âmbito judicial pois, normalmente, juízes exercem certo tipo de controle, por exemplo, quando utilizam linguagem hermética, a dificultar a compreensão das partes e demais pessoas não habituadas à linguagem jurídica. Ou seja, o estabelecimento ou reforço da não compreensão sobre determinados tópicos pode ser visto, com efeito, como uma forma efetiva de controle de certos indivíduos (ou grupos) sobre outros.

Aliás, há duas premissas dos ECD de van Dijk sobre o poder que estão em consonância com o que argumentam alguns estudiosos do Direito: i) o poder envolve a capacidade de certos grupos subordinarem outros; ii) o poder jurídico, como outras formas de poder, tem um relacionamento íntimo com a desigualdade. O estudo do poder deve, portanto, voltar-se à questão fundamental da desigualdade, ou seja, por que ela existe e como ela se mantém ${ }^{44}$.

Nesse diapasão, a respeito das desigualdade, o poder exerce diversas formas de dominação, que resultam em injustiças sociais e podem ser desveladas por meio de um estudo crítico dos discursos jurídico e político. Para perceber mais nitidamente de que forma o poder é exercido, é importante observá-lo do ponto de vista da interação social, como uma forma de controle social, que pressupõe sempre a existência de uma estrutura ideológica, formada por cognições fundamentais que são socialmente compartilhadas, relacionando-se com os interesses de um grupo e seus membros. O modo como essa estrutura é confirmada e alterada se opera, especialmente, por meio da comunicação e do discurso ${ }^{45}$. De acordo com Pierre Bourdieu,

é enquanto instrumentos estruturados e estruturantes de comunicação e de conhecimento que os < sistemas simbólicos> cumprem a sua função política de instrumentos de imposição ou de legitimação da dominação, que contribuem para assegurar a dominação de uma classe sobre outra (violência simbólica) dando o reforço da sua própria força às relações de força que as fundamentam e contribuindo assim, segundo a expressão de Weber, para a $<$ domesticação dos dominados $>^{46}$.

\footnotetext{
40 DIJK, Teun A. van. Discurso e Poder. Org. Hoffnagel, Judith e Falcone, Karina. $2^{\mathrm{a}}$ ed. $1^{\mathrm{a}}$ reimpressão. São Paulo: Contexto, 2012, p. 24.

${ }^{41}$ FOWLER, Roger. Power. In: DIJK, Teun A. Handbook of Discourse Analysis, Vol. 4: Discourse Analysis in Society. Orlando: Academic Press, 1985, p. 61. Tradução livre de: “(...) power is the ability of people and institutions to control the behavior and material lives of others". 42 WODAK, Ruth. What CDA is about - a summary of its history, important concepts and its developments. In: WODAK, Ruth and MEYER, Michael. Methods of Critical Discourse Analysis. London: SAGE Publications, 2002, p. 11.

43 WODAK, Ruth. What CDA is about - a summary of its history, important concepts and its developments. In: WODAK, Ruth and MEYER, Michael. Methods of Critical Discourse Analysis. London: SAGE Publications, 2002, p. 11.

44 DIJK, Teun A. van. Discurso e Poder. Op. cit., pp.10 e ss; CONLEY, John M. and O’BARR, William M. Just Words: Law, Language and Power. Chicago: The University of Chicago Press, 1998, p. 8.

45 DIJK, Teun A. van. Discurso e Poder. Org. Hoffnagel, Judith e Falcone, Karina. $2^{\mathrm{a}}$ ed. $1^{\mathrm{a}}$ reimpressão. São Paulo: Contexto, 2012 , pp. 41-43.

46 BOURDIEU, Pierre. O Poder Simbólico. Trad. de Fernando Tomaz. Rio de Janeiro: Editora Bertrand Brasil, 1989, p.11.
} 
No âmbito da Análise Crítica do Discurso (ACD) — dos quais derivam os ECD, conforme salientamos anteriormente -, Ruth Wodak revela que a ideologia "é vista como um aspecto importante para estabelecer e manter relações desiguais de poder", por isso "um dos objetivos da ACD é 'desmistificar' os discursos por meio da decifração das ideologias" ${ }^{\prime 7}$. Mas, como podemos identificar se um discurso é, de fato, ideológico? Norman Fairclough responde dizendo que "o discurso é ideológico na medida em que contribui para sustentar relações particulares de poder e dominação" "48. Trata-se, portanto, de detectar como determinados discursos operam no sentido de se estabelecerem relações de dominação social.

Para além das ideias da ACD, podemos salientar, a partir dos ECD de van Dijk, que “(...) a análise ideológica do discurso deve ser vista como um tipo específico de análise sociopolítica do discurso. Essa análise, entre outras coisas, tenta relacionar as estruturas do discurso com as estruturas da sociedade" ${ }^{49}$. Seja no campo do discurso jurídico ou do discurso político (como em tantos outros discursos), há sempre uma ideologia associada. Portanto, entender o modo como esses discursos se relacionam e como podem ser orientados por uma ideologia comum são pontos de especial interesse para este artigo. Perceberemos, nesse sentido, como existe uma espécie de "luta" no campo discursivo, visando à manutenção das ideologias associadas às posições dos diferentes atores sociais (políticos e jurídicos). Van Dijk defenderá que o papel da análise ideológica nos ECD é, primordialmente, o de examinar quais são as ideologias tipicamente associadas a essas posições, bem como o modo como se defendem ou legitimam por meio do discurso. Assim, nas relações de dominação, o discurso ideológico torna-se, muitas vezes, mecanismo de sustentação ou resistência a determinadas posições sociais ${ }^{50}$. E essas posições se sustentam, obviamente, por meio do poder.

Especificamente no que se refere aos dispositivos de racialidade, note-se como o ideário racista se sustenta, segundo Sueli Carneiro ${ }^{51}$, na "capacidade de naturalizar a sua concepção sobre o Outro". Portanto, "é preciso que as palavras, as coisas, a forma e o conteúdo coincidam para que a ideia possa se naturalizar". Assim, a justificação para a desigualdade, sob essa ótica, encontra sustentação na realidade material por ela produzida.

É importante, nesse contexto, delinearmos uma concepção teórica de racismo a partir do ponto de vista dos ECD de van Dijk, para compreender como o discurso pode reforçar e naturalizar a desigualdade racial. Van Dijk diz que o racismo pode ser "entendido como um complexo sistema social de dominação, fundamentado étnica ou 'racialmente'..." ${ }^{\prime \prime}$, composto por um subsistema social e por um subsistema cognitivo. O primeiro constitui-se por "práticas sociais de discriminação no (micro) nível local, e por relações de abuso de poder por grupos, organizações e instituições dominantes em um (macro) nível de análise"53. O segundo, por sua vez, sugere a existência de uma base mental, geralmente forjada em "modelos tendenciosos de interações e eventos étnicos”. Mais especificamente, são representações mentais negativas, compartilhadas

\footnotetext{
47 WODAK, Ruth. What CDA is about - a summary of its history, important concepts and its developments. In: WODAK, Ruth and MEYER, Michael. Methods of Critical Discourse Analysis. London: SAGE Publications, 2002, pp. 10-11. Tradução livre de: "Ideology, for CDA, is seen as an important aspect of establishing and maintaining unequal power relations". (...) "one of the aims of CDA is to 'demystify' discourses by deciphering ideologies".

48 FAIRCLOUGH, Norman. Critical discourse analysis as a method in social scientific research. In: WODAK, Ruth and MEYER, Michael. Methods of Critical Discourse Analysis. London: SAGE Publications, 2002, p. 126. Tradução livre de: “(...) discourse is ideological in so far as it contributes to sustaining particular relations of power and domination".

49 DIJK, Teun A. van. Ideological Discourse Analysis. In: New Courant (English Dep., University of Helsinki), 4 (1995), pp. 135161. Special issue Interdisciplinary approaches to Discourse Analysis, ed. by Eija Ventola and Anna Solin, p. 135. Tradução livre de: "(...) ideological discourse analysis should be seen as one specific type of socio-political analysis of discourse. Such an analysis, among other things, attempts to relate structures of discourse with structures of society"

50 DIJK, Teun A. van. Ideological Discourse Analysis. In: New Courant (English Dep., University of Helsinki), 4 (1995), p. 136.

51 CARNEIRO, Aparecida Sueli. A Construção do Outro como Não-Ser como fundamento do Ser. Tese de Doutorado. São Paulo: Feusp, 2005, pp. 29-30.

52 DIJK, Teun A. van. Ideological Discourse Analysis. In: New Courant (English Dep., University of Helsinki), 4 (1995), p. 134.

53 DIJK, Teun A. van. Ideological Discourse Analysis. In: New Courant (English Dep., University of Helsinki), 4 (1995), p. 134.
} 
socialmente, acerca de "nós" sobre "eles" ${ }^{54}$. Assim, conforme Sueli Carneiro 55 , "o dispositivo de racialidade beneficia-se das representações construídas sobre o negro durante o período colonial no que tange aos discursos e práticas que justificaram a constituição de senhores e escravos, articulando-os e resignificando-os à luz do racialismo vigente no século XXI".

Nesse sentido, é importante reconhecer que o racismo, conforme Bruno Barros e Rita Albrecht, "constitui fator permanente na sociedade na medida em que ele é o produto de uma longa elaboração histórica e não intelectual. É por isso que a luta pela diversidade e pluralismo racial, a luta contra o racismo, deve, também, ser um fator permanente da sociedade (...)" ${ }^{n 6}$.

Antes de passarmos ao estudo crítico do discurso de Jair Bolsonaro, é importante destacarmos que, para van Dijk, não existe um modo padrão de se realizar uma análise ou estudo crítico do discurso. Não obstante, em sentido amplo, o autor propõe que se sigam cinco pontos para a realização de uma análise ideológica dos discursos, são eles: a) examinar o contexto do discurso; b) analisar que grupos, relações de poder e conflitos estão nele envolvidos; c) pesquisar opiniões positivas e negativas sobre a polarização "nós" / "eles"; d) explicitar o pressuposto e o implícito no discurso e, finalmente, e) estudar todas as estruturas formais que (des)enfatizam as opiniões do grupo polarizado ${ }^{57}$.

Para a concretização desse modelo, a análise do discurso pode perpassar o estudo das seguintes estruturas e das estratégias linguísticas ${ }^{58}$ descritas por van Dijk $\mathrm{k}^{59}$ : a) Tópicos: macro-estruturas semânticas; b) Significados locais (lexicais); c) Estruturas "formais" sutis; d) Modelos contextuais; e) Modelos de acontecimentos; f) Cognição social; g) Discurso e sociedade.

\subsection{Autoapresentação positiva, outroapresentação negativa e o "racismo recreativo" de Bolsonaro}

Tendo realizado a contextualização histórica dos atores sociais envolvidos e apresentado alguns lineamentos teóricos basilares dos ECD, passaremos, agora, ao estudo crítico do discurso de Bolsonaro em sua palestra no Clube Hebraica Rio. Escolhemos, para tanto, dois trechos que a nosso ver evidenciam o alinhamento dos interesses do então pré-candidato à presidência com os interesses da iniciativa privada, ao tempo em que demonstram a polarização entre o endogrupo (nós) e o exogrupo (eles), notadamente por meio da depreciação dos quilombolas:

(1) Aqui apenas ó. São as reservas indígenas no Brasil né, onde têm uma reserva indígena, tem uma riqueza embaixo dela. Temos que mudar isso daí! Mas nós não temos hoje em dia mais autonomia para mudar isso daí. Entregou-se tanto nossa nação que chegamos a esse ponto. Mas dá pra mudar o

54 DIJK, Teun A. van. Ideological Discourse Analysis. In: New Courant (English Dep., University of Helsinki), 4 (1995), pp. 134135.

55 CARNEIRO, Aparecida Sueli. A Construção do Outro como Não-Ser como fundamento do Ser. Tese de Doutorado. São Paulo: Feusp, 2005 , p. 50 .

56 BARROS, Bruno Mello Correa de e ALBRECHT, Rita Mara. A discriminação racial no Brasil e a ascensão do povo negro: um olhar a partir dos princípios constitucionais na luta pela cidadania inclusiva. In: Revista Brasileira de Políticas Públicas, Vol. 9, N. 1, pp. 14-33, 2019. Disponível em: <https://www.publicacoesacademicas.uniceub.br/RBPP/article/view/5908>. Acesso em 19 de maio de 2020, p. 21.

57 DIJK, Teun A. van. Opinions and Ideologies in the Press. Paper Round Table on Media Discourse. Cardiff, July 08-10, 1995. In: BELL, Allan and GARRETT, Peter (Eds.). Approaches to Media Discourse. Oxford: Blackwell, 1998, p. 61.

58 Esta metodologia começou a ser desenvolvida de modo mais detalhado por van Dijk ainda nos anos 1990, época em que o autor ainda a atribuía ao âmbito da Análise Crítica do Discurso (ACD). Contudo, como foi referido na primeira parte deste trabalho, recentemente van Dijk vem designando seu movimento científico como Estudos Críticos do Discurso (Critical Discourse Studies). Para tanto, ver DIJK, Teun A. van. Discurso e Poder. Org. Hoffnagel, Judith e Falcone, Karina. $2^{\mathrm{a}}$ ed. $1^{\mathrm{a}}$ reimpressão. São Paulo: Contexto, 2012, especialmente p. 09 e seguintes.

59 DIJK, Teun A. van. Discurso, Notícia e Ideologia: estudos na Análise Crítica do Discurso. Trad. Zara Pinto-Coelho. Colecção Comunicação e Sociedade. Porto: Campo das Letras, 2005. 
nosso país! Isso aqui é só reserva indígena, tá faltando quilombolas... é outra brincadeira.

(2) Eu fui num quilombola em Eldorado Paulista... olha, o afrodescendente mais leve lá, pesava sete arrobas... não fazem nada! Eu acho que nem pra procriadores servem mais... mais de um bilhão de reais por ano gastado com eles.

Inicialmente, cabe observar que o direito à regulamentação das terras dos remanescentes das comunidades quilombolas deve ser considerado pela perspectiva mais ampla de acesso aos direitos humanos/fundamentais. Para essa população, assim como para os indígenas, a territorialidade guarda relação direta com o processo de formação identitária ${ }^{60}$, profundamente imbricado com a vida comunitária, a estabelecer uma relação de pertença com a terra, oposta à concepção liberal de propriedade privada. Assim, o racismo está claramente presente na criação de um projeto político que visa restringir o acesso da comunidade quilombola aos seus direitos constitucionalmente reconhecidos, consubstanciado na imposição de impedimentos aos processos de certificação de suas terras e, consequentemente, na supressão, pelo Estado, de um dos elementos indispensáveis na formação da identidade daquela população, comprometendo sua sobrevivência. Não se pode olvidar que é dever do Estado respeitar os tratados internacionais de direitos humanos dos quais é signatário e que se encontram incorporados ao seu arcabouço jurídico, não apenas no sentido de deixar de praticar atos que venham a tolher direitos e liberdades individuais, mas efetivamente realizar ações que visam dar concretude à dignidade humana, sem distinções de raça, gênero, classe, religião, etnia etc., com respeito à diversidade cultural e histórica dos grupos sociais. Por isso, parece-nos fundamental observar, com Barros e Albrecht, que "se o racismo resiste hoje com a virulência que possui, expandindo-se cada vez mais, apesar de todos os esforços morais e culturais e de todos os avanços no conhecimento científico sobre as diferenças humanas, é porque tem se convertido ao longo do tempo numa realidade tenaz, arraigada na consciência e na prática social" ${ }^{61}$.

Do ponto de vista linguístico, por meio da análise dos significados locais (lexicais), torna-se possível perceber a polarização entre o endogrupo (nós) e o exogrupo (eles) no discurso de Bolsonaro. Segundo van Dijk, é por meio dos significados dos tópicos presentes nos níveis macro e microestruturais que se percebe, de forma mais clara, a estratégia de autoapresentação positiva e de outroapresentação negativa ${ }^{62}$.

O recurso a esse tipo de estratégia pode ser melhor percebido logo no primeiro trecho selecionado, quando Bolsonaro afirma: “(Nós) temos de mudar isso aí...”. Trata-se, com efeito, de um discurso marcadamente persuasivo, proferido por um político brasileiro que surge, neste contexto, como uma espécie de representante privilegiado da maioria dominante (branca, masculina, conservadora). Para além disso, Bolsonaro pode ser visto como membro de uma elite que possui o acesso às formas mais influentes do discurso público. Parece-nos importante sublinhar, com van Dijk, que a definição de elite aqui não se dá em termos de posições sociais de liderança, mas sim

em termos dos recursos simbólicos que definem o 'capital' simbólico e, em particular, seu acesso preferencial ao discurso público. As elites, assim definidas, são literalmente o(s) grupo(s) na sociedade que mais têm 'algo a dizer e que, portanto, também tem 'acesso preferencial às mentes' do grande público ${ }^{63}$.

Em seguida, Bolsonaro, contraditoriamente, afirma que “(...) nós não temos hoje em dia mais autonomia para mudar isso daí. Entregou-se tanto nossa nação que chegamos a esse ponto”, para concluir dizendo:

${ }^{60}$ SOUZA, Barbara Oliveira. Aquilombar-se: Panorama Histórico, Identitário e Político do Movimento Quilombola Brasileiro. Brasília, 2008, p. 84 .

61 BARROS, Bruno Mello Correa de e ALBRECHT, Rita Mara. A discriminação racial no Brasil e a ascensão do povo negro: um olhar a partir dos princípios constitucionais na luta pela cidadania inclusiva. In: Revista Brasileira de Políticas Públicas, Vol. 9, N. 1, pp. 14-33, 2019. Disponível em: <https://www.publicacoesacademicas.uniceub.br/RBPP/article/view/5908>. Acesso em 19 de maio de 2020, p. 20.

62 DIJK, Teun A. van. Discurso, Notícia e Ideologia: estudos na Análise Crítica do Discurso. Trad. Zara Pinto-Coelho. Colecção Comunicação e Sociedade. Porto: Campo das Letras, 2005, p. 43.

63 DIJK, Teun A. van. Discurso e Poder. Org. Hoffnagel, Judith e Falcone, Karina. $2^{a}$ ed. $1^{\text {a }}$ reimpressão. São Paulo: Contexto, 2012, p. 139. 
"Mas dá pra mudar o nosso país!". Como salientamos, Bolsonaro apela, em sua fala, a um recurso típico da organização do discurso racista: a estratégia da autoapresentação positiva e outroapresentação negativa ${ }^{64}$. $\mathrm{O}$ apelo a esse recurso discursivo consiste em movimentos semânticos com uma parte positiva ("Nós podemos mudar o país") e com uma outroapresentação negativa (índios, afrodescendentes pesando "sete arrobas" que não fazem nada etc.). Expressões corriqueiras, indicativas de algum tipo de polarização social — como "nós" e "eles" - , são um exemplo típico da presença de ideologias no âmbito do discurso. Somam-se a expressões como estas (que indicam identidade) as atividades, os valores, a posição e os recursos de um determinado grupo, o que acaba por sustentar e reproduzir conflitos sociais, dominação e desigualdade ${ }^{65}$.

Do ponto de vista filosófico, Carneiro ${ }^{66}$ menciona que "o dispositivo de racialidade ao demarcar o estatuto humano como sinônimo de brancura irá, por consequência, redefinir todas as demais dimensões humanas e hierarquizá-las de acordo com a sua proximidade ou distanciamento desse padrão". Ou seja, a polarização "nós" / "eles" acaba por ser a base de muitos discursos ideológicos que cristalizam relações de abuso de poder. Por outro lado, a ideia de uma superioridade branca, masculina, colonizadora, personificada no orador e em $75 \%$ dos congressistas brasileiros ${ }^{67}$, passa também pela ideia do Estado como agente "civilizador" aos moldes coloniais ${ }^{68}$.

A visão racista de Bolsonaro pode ser melhor percebida quando o parlamentar salienta uma suposta inferioridade dos quilombolas, quem sabe por se tratarem de indivíduos negros, descendentes de ex-escravos e trabalhadores rurais, que possuem uma relação orgânica com a terra e uma vida comunitária simples. Tal visão parece ficar bastante nítida no segundo trecho anteriormente referido, quando, servindo-se de um tipo de "racismo recreativo" 69 , Bolsonaro se utiliza de uma polêmica expressão para se referir, em tom sarcástico, aos quilombolas: "olha, o afrodescendente mais leve lá, pesava sete arrobas".

Arroba, como se sabe, é uma unidade de massa historicamente utilizada pelos negociadores de escravos, sendo ainda hoje utilizada no meio agropecuário para a pesagem de animais vivos, nomeadamente bovinos. Ou seja, ou Bolsonaro estaria resgatando, de maneira um tanto infeliz, uma expressão histórica e se referindo aos afrodescendentes como escravos gordos (sete arrobas equivalem, hoje, em média, a $105 \mathrm{~kg}$ ), ou estaria se referindo aos negros como animais, embora as marcas do discurso bolsonarista em diferentes situações sugiram o primeiro caso.

Os tópicos do discurso de Bolsonaro expressam seu modelo mental acerca das reservas índigenas e das comunidades quilombolas, modelo que pode ser analiticamente disposto da seguinte forma:

(T1) Reservas indígenas são ricas e encontram-se em mãos erradas.

(T2) Precisa-se explorar a riqueza que há nas reservas indígenas.

${ }^{64}$ DIJK, Teun A. van. Discurso e Poder. Org. Hoffnagel, Judith e Falcone, Karina. $2^{a}$ ed. $1^{\text {a }}$ reimpressão. São Paulo: Contexto, 2012, p. 142 e ss. Ver também: DIJK, Teun A. van. Discurso, Notícia e Ideologia: estudos na Análise Crítica do Discurso. Trad. Zara PintoCoelho. Colecção Comunicação e Sociedade. Porto: Campo das Letras, 2005, p. 43 e DIJK, Teun A. van. Opinions and Ideologies in the Press. Paper Round Table on Media Discourse. Cardiff, July 08-10, 1995. In: BELL, Allan and GARRET'T, Peter (Eds.). Approaches to Media Discourse. Oxford: Blackwell, 1998, pp. 62-63.

${ }_{65}$ DIJK, Teun A. van. El discurso como interacción en la sociedad. In: DIJK, Teun A. van (Comp.). El Discurso como Interacción Social. Estudios sobre el discurso II: Una introducción multidisciplinaria. Barcelona: Gedisa, 2008, pp. 60-61.

${ }^{6}$ CARNEIRO, Aparecida Sueli. A Construção do Outro como Não-Ser como fundamento do Ser. Tese de Doutorado. São Paulo: Feusp, 2005, p. 43.

67 Levantamento realizado pelo portal G1 acerca do perfil dos deputados eleitos no Brasil em 2018. Ver: G1. "Perfil médio do deputado federal eleito é homem, branco, casado e com ensino superior". Disponível em: <https://g1.globo.com/politica/eleicoes/2018/eleicao-em-numeros/noticia/2018/10/21/perfil-medio-do-deputado-federal-eleito-e-homem-branco-casado-e-comensino-superior.ghtml>. Acesso em: 27 de março de 2020.

68 CARONE, Iray e BENTO, Maria Aparecida Silva, (org.). Psicologia Social do Racismo: Estudos sobre branquetude e branqueamento no Brasil. $\sigma^{a}$ ed. Petropólis: Vozes, 2014, p. 15.

69 Para utilizarmos aqui uma expressão de MOREIRA, Adilson. Racismo recreativo. São Paulo: Pólen, 2019. Nesse sentido, ver também SANTOS, Fernando do Nascimento. Bolsonaro x Quilombola: racismo recreativo e institucional e a invisibilidade do insulto moral. In: Revista Liberdades, n. 27, IBCCRIM, jan-jun de 2019. 
(T3) Quilombolas são gordos, preguiçosos e não gostam de trabalhar.

(T4) O país não deve investir na preservação de povos indígenas e comunidades quilombolas.

$\mathrm{Na}$ perspectiva dos ECD, modelos mentais são considerados interpretações subjetivas, pessoais, incompletas, tendenciosas ou, até mesmo, imaginárias. Esses modelos são criados com base no contexto global e interacional da situação comunicativa. Segundo van Dijk, modelos mentais consistem, portanto, na "representação esquemática das dimensões pessoal e socialmente relevantes dos acontecimentos, tais como localização (espacial, temporal), participantes (em vários papéis), ações" ${ }^{70}$.

Ao atribuir à comunidade quilombola e indígena a responsabilidade pelos entraves ao desenvolvimento econômico do país, em função de seu território e das riquezas naturais nele contidas, ao comparar os quilombolas à escravos e/ou animais, resgatando expressões utilizadas historicamente pelos negociadores de escravos e ainda hoje por agropecuaristas, ao projetar em seu discurso a ideia de que os quilombolas são inúteis economicamente para o país e que os recursos públicos destinados às suas comunidades são gastos de dinheiro público desnecessários, Bolsonaro não apenas apresenta a comunidade quilombola negativamente, mas pugna por apoio popular ao seu projeto político de extermínio dessa população - como se tudo fosse resumido apenas à questão da propriedade privada daquelas terras.

A suposição da superioridade moral da sociedade brasileira, baseada na Teoria da Democracia Racial Freyreana, em comparação ao racismo estadunidense e sul-africano institucionalizado ${ }^{71}$, fez, de maneira curiosa, emergir no Brasil uma "sociedade racista sem racistas". Um bom exemplo disso é o racismo recreativo expresso nas piadas de Bolsonaro, que naturalizam expressões vexatórias e comportamentos discriminatórios em relação aos negros. Por posturas como estas que Bolsonaro passou a ser largamente reconhecido em solo brasileiro por seu envolvimento em casos de racismo e misoginia divulgados pela imprensa, corroborando a extrapolação de discursos negativos ainda tão presentes na sociedade contemporânea, conforme observam Deysi Cioccari e Simonetta Persichetti ${ }^{72}$. Cabe, por conseguinte, estudarmos a recepção e interpretação pelo Judiciário do discurso de Bolsonaro no Clube Hebraica Rio.

\subsection{Estudo crítico do discurso judicial}

Como referimos anteriormente, o discurso de Bolsonaro no Clube Hebraica Rio rendeu ao político dois processos judiciais. Analisaremos brevemente, a seguir, alguns aspectos do Acórdão que reformou a sentença proferida pela Juíza Federal Frana Elizabeth Mendes, da 26 Vara Federal da Seção Judiciária do Rio de Janeiro, ao julgar a Ação Civil Pública de N. ${ }^{o}$ 0101298-70.2017.4.02.5101, proposta pelo Ministério Público Federal (MPF). O MPF, por sua vez, foi provocado pela Coordenação Nacional das Comunidades Negras Rurais Quilombolas (CONAQ) em parceria com a Organização Terra de Direitos.

Em 25 de setembro de 2017, Mendes condenou Jair Bolsonaro — pedido de indenização no valor de R \$ 300.000,00, por danos morais coletivos, julgado parcialmente procedente — ao pagamento de indenização no montante de $\mathrm{R} \$ 50.000,00$, revertido ao Fundo Federal de Defesa dos Direitos Difusos. Como mencionado, tal decisão foi reformada pela $8^{a}$ Turma Especializada do Tribunal Regional Federal da $2^{a}$ Região, cujo Acórdão teve relatoria do Desembargador Marcelo Pereira da Silva. Nosso estudo, logo, focar-se-á nos aspectos que entendemos problemáticos e/ou merecedores de interesse do Acórdão relatado por Silva.

\footnotetext{
70 DIJK, Teun A. van. Discurso, Notícia e Ideologia: estudos na Análise Crítica do Discurso. Trad. Zara Pinto-Coelho. Colecção Comunicação e Sociedade. Porto: Campo das Letras, 2005, p. 52.

71 HERNÁNDEZ, Tanya Katerí. A Inocência Racial, o Direito Costumeiro e a Nova Resposta dos Direitos Civis. Trad. de Ariovaldo Santos de Souza e Luciana Carvalho Fonseca. Salvador: EDUFBA, 2017, p. 21.

72 CIOCCARI, Deysi e PERSICHETTI, Simonetta. Armas, ódio e espetáculo em Jair Bolsonaro. In: Revista Alterjor, Grupo de Estudos Alterjor: Jornalismo Popular e Alternativo (ECA-USP) Ano 09, Volume 02, Edição 18, Julho-Dezembro de 2018. Disponível em: <http://www.revistas.usp.br/alterjor/article/view/144688>. Acesso em: 18 de maio de 2020, pp. 202-203.
} 
Com efeito, se, na primeira sentença, Frana Mendes apura a existência de possível abuso no exercício do direito à liberdade de expressão, destacando com acerto que esse direito não é absoluto, "encontrando limites éticos, morais e sociais de respeito ao próximo e à coletividade"73, em uma (necessária) tentativa judicial de limitar a ideologia e o racismo de uma elite cultural e social (que, não raro, menospreza minorias), a argumentação de Marcelo Silva, por sua vez, parece apontar para uma velada afinidade com os valores dessa elite, muitos dos quais assegurados pelo próprio Direito.

Nesse sentido, não podemos, ingenuamente, acreditar que estamos diante de uma habitual decisão judicial versando sobre um dado conflito ideológico em um contexto democrático, pois nem todas as relações de poder orientadas por ideologias dão margens ao que José Rodrigues Silva chamou de "diálogo ideológico". Ou seja, não se trata, na circunstância, de um diálogo. Um diálogo ideológico só é possível se a democracia for previamente institucionalizada, senão vivida, pois, na ausência de garantias democráticas efetivas, a confrontação ideológica obedece forçosamente à lei do mais forte ${ }^{74}$. Essa confrontação ideológica - estabelecida a partir da fala de Bolsonaro - é típica de um déficit democrático, como este que vivemos nesses tempos obscuros e intolerantes.

Feitas tais considerações iniciais, cabe transcrevermos a primeira parte da argumentação de Marcelo Silva, visando contextualizar certos aspectos jurídicos:

I - O Supremo Tribunal Federal já consagrou o entendimento de que a imunidade material dos deputados e senadores, na redação da Emenda Constitucional 35/2001 ao art. 53 da CF, abrangeria as opiniões, palavras e votos proferidos em virtude da condição de parlamentar, estendendo-se, portanto, a qualquer lugar do território nacional em que estiver o deputado ou senador atuando em razão de suas funções parlamentares, somente deixando de alcançar as manifestações sobre matéria alheia ao exercício do mandato ${ }^{75}$.

A passagem acima serve de mote para trazermos à discussão o entendimento de Silva, amparado no entendimento do STF sobre a imunidade material de deputados e senadores que, em nossa visão, não parece aplicável ao caso em tela. Referimo-nos ao fato, reconhecido pelo próprio julgador no Acórdão (mas não devidamente separado em forma e fundo), de Bolsonaro estar palestrando no Clube Hebraica Rio não apenas na condição de Deputado Federal, mas, sobretudo, como pré-candidato à Presidência da República, para expor suas ideias e propostas políticas ${ }^{76}$. Para Silva, é "inegável o nexo de causalidade entre as atividades parlamentares do Réu e a palestra realizada" ${ }^{77}$. Todavia, parece-nos difícil sustentar tão facilmente o referido nexo de causalidade. A mera invocação do entendimento do STF sobre o assunto - sem reconhecer as peculiaridades do convite e as "intenções presidenciáveis" (sempre claras, note-se) de Bolsonaro para a pa-

73 BRASIL. Poder Judiciário. Justiça Federal. Seção Judiciária do Rio de Janeiro. 26 a Vara Federal da Seção Judiciária do Rio de Janeiro. Ação Civil Pública No 0101298-70.2017.4.02.5101. Autores: Ministério Público Federal e outro. Réu: Jair Messias Bolsonaro. Julgador(a): Frana Elizabeth Mendes, Juíza Federal. Rio de Janeiro, 25 de setembro de 2017. Disponível em: < https://politica.estadao.com.br/blogs/fausto-macedo/wp-content/uploads/sites/41/2017/10/76994222-50-1-pp.pdf>. Acesso em: 15 de abril de 2020, pp. 04-05.

74 SILVA, José M. Rodrigues. O Homem e o Poder. Lisboa: Bertrand Editora/Venda Nova, 1988, pp. 151-152.

75 BRASIL. Poder Judiciário. Tribunal Regional da $2^{\mathrm{a}}$ Região. Apelação Cível. Turma Especial III. Administrativo e Cível. No CNJ: 0101298-70.2017.4.02.5101 [2017.51.01.101298-3]. Relator: Desembargador Federal Marcelo Pereira da Silva. Apelante: Ministério Público Federal e outros. Procurador: Procurador Regional da República e outros. Apelado: os mesmos. Origem: 26ª Vara Federal do Rio de Janeiro [01012987020174025101]. Disponível em: <https://www.migalhas.com.br/arquivos/2018/9/art20180925-04. pdf>. Acesso em: 12 de abril de 2020, p. 01.

76 BRASIL. Poder Judiciário. Tribunal Regional da $2^{\mathrm{a}}$ Região. Apelação Cível. Turma Especial III. Administrativo e Cível. No CNJ: 0101298-70.2017.4.02.5101 [2017.51.01.101298-3]. Relator: Desembargador Federal Marcelo Pereira da Silva. Apelante: Ministério Público Federal e outros. Procurador: Procurador Regional da República e outros. Apelado: os mesmos. Origem: 26ª Vara Federal do Rio de Janeiro [01012987020174025101]. Disponível em: <https://www.migalhas.com.br/arquivos/2018/9/art20180925-04. pdf>. Acesso em: 12 de abril de 2020, p. 01.

77 BRASIL. Poder Judiciário. Tribunal Regional da $2^{a}$ Região. Apelação Cível. Turma Especial III. Administrativo e Cível. No CNJ: 0101298-70.2017.4.02.5101 [2017.51.01.101298-3]. Relator: Desembargador Federal Marcelo Pereira da Silva. Apelante: Ministério Público Federal e outros. Procurador: Procurador Regional da República e outros. Apelado: os mesmos. Origem: $26^{a}$ Vara Federal do Rio de Janeiro [01012987020174025101]. Disponível em: <https://www.migalhas.com.br/arquivos/2018/9/art20180925-04. pdf $>$. Acesso em: 12 de abril de 2020, p. 01. 
lestra no Clube Hebraica — parece ser o passo mais fácil para Silva evitar a responsabilização de Bolsonaro pela sua fala racista.

A nosso ver, o nexo de causalidade entre a atividade parlamentar de Bolsonaro e a palestra deveria ter sido objeto de análise mais rigorosa e aprofundada pelo magistrado. Ora, o reconhecimento do nexo causal foi sustentado tão-somente no suposto convite de Bolsonaro como deputado federal ${ }^{78}$, no entanto, ao final do vídeo é possível ouvir o presidente do Clube agradecer a presença do parlamentar como pré-candidato à presidência, além da abstração do magistrado para o fato de Bolsonaro se encontrar em franca campanha presidencial.

É cediço que faz parte do ofício de deputado "palestrar" em clubes, associações, instituições de ensino etc. para divulgar seus projetos e ideias. Contudo, o não reconhecimento, na ocasião, dos distintos papéis sociais $^{79}$ de Bolsonaro parece ter sido decisivo para o não afastamento da imunidade parlamentar pelo magistrado. Não se deveria ignorar aqui o fato (sociológico, diga-se) de que as expectativas dos outros se dirigem a nós (isto é, aos papéis que socialmente desempenhamos) de modo a exigir, de nossa parte, uma determinada conduta, uma determinada ação. Todavia, se é naturalmente esperado ou mesmo aceitável que um parlamentar profira toda essa carga de preconceitos - o qual restaria intocado pelo fato deste estar sob o manto da imunidade - , deveríamos começar urgentemente a refletir sobre a possibilidade de inclusão de mecanismos jurídicos para a retirada deste manto naquelas circunstâncias em que visivelmente se excedem os limites, atingindo a dignidade de indivíduos e grupos.

É, assim, abordando a motivação eleitoral de Bolsonaro, que se passa a outro trecho importante (e quem sabe o mais problemático) do Acórdão:

III - (I) Quanto à alegação de que a motivação eleitoral do candidato ao cargo da Presidência da República afastaria a aplicabilidade da imunidade parlamentar, verifica-se que a mesma não guarda sintonia com o caso dos autos, na medida em que os precedentes jurisprudenciais do Supremo Tribunal Federal que consagram tal entendimento têm por fundamento o postulado republicano da não discriminação entre candidatos a um mesmo cargo político.

(II) No caso dos autos, porém, No caso dos autos, porém, (sic) em que pese já estivesse o Réu em pré-campanha para a Presidência da República pelo Partido Social Cristão desde a data de sua filiação em março de 2016, a verdade é que os comentários discriminatórios por ele desferidos em 03.04.2017 na Hebraica em desfavor dos quilombolas não o colocaram em posição de vantagem anti-isonômica em relação aos demais pré-candidatos ao cargo pretendido ao cargo pretendido (sic), ao que se sabe nenhum descendente de quilombolas.

Embora compondo um único parágrafo no Acórdão, dividimos a argumentação do magistrado em duas partes (I e II), visando, assim, facilitar o nosso estudo. Na parte I, ao negar a tentativa de afastamento da imunidade parlamentar com base na motivação eleitoral de Bolsonaro ao cargo da Presidência da República, Silva alega o respeito aos precedentes do STF e ao "postulado republicano da não discriminação entre candidatos a um mesmo cargo político". Nesse caso, porém, utiliza-se a imunidade parlamentar (uma garantia) para proteger da acusação de racismo um pré-candidato à presidência sob o estranho argumento de não discriminação entre candidatos. A imunidade parlamentar surge, desse modo, como uma espécie de capa protetora, como um critério diferenciador do diferente que não pode ser diferenciado.

\footnotetext{
78 O que foi confirmado inclusive por declaração assinada pelo Presidente do Clube Hebraica do Rio de Janeiro, Luiz Mairovitch, segundo o qual Bolsonaro foi convidado para "proceder à exposição de visão geopolítica e econômica do País". Cfe.: BRASIL. Supremo Tribunal Federal. Primeira Turma. Inquérito N. o 4.694. Distrito Federal. Relator: Ministro Marco Aurélio. Autor: Ministério Público Federal. Proc.(a/s)(es): Procurador-Geral da República. Invest.(a/s): Jair Messias Bolsonaro. Adv. (a/s): Antônio Sérgio Altieri de Moraes Pitombo e outros (a/s). Data: 11/09/2018. Disponível em: <https://stf.jusbrasil.com.br/jurisprudencia/768164396/inquerito-inq-4694-df-distrito-federal-0016317-5720181000000/inteiro-teor-768164398? ref=serp>. Acesso em: 12 de abril de 2020, p. 09.

79 É possível encontrar em DAHRENDORF, Ralf. Homo Sociologicus. Trad. de Freitas e Silva. Lisboa: Quetzal, 2012 uma das mais interessantes e célebres discussões em torno dos papéis sociais — não obstante importantes sociólogos, como Durkheim e Weber, tenham também se dedicado ao assunto.
} 
Por conseguinte, na parte II — trecho, aliás, carregado de problemas de sintaxe e/ou digitação no documento original - tem-se uma tentativa (um pouco distorcida, reconheça-se) de Silva em observar as hipotéticas consequências do racismo de Bolsonaro para sua candidatura à Presidência da República. Assim, com base no argumento (algo tendencioso, neste caso) de que Bolsonaro restaria prejudicado pelos seus próprios preconceitos, visto que seus potenciais eleitores, possivelmente, o criticariam pelas "incontinências verbais", o magistrado acaba por minimizar o discurso discriminatório do parlamentar. Abstrai-se, assim, os reais afetados com o discurso de Bolsonaro: os quilombolas.

Nesse mesmo trecho, Silva reconhece que Bolsonaro, em sua palestra, teceu "comentários discriminatórios", qualificando-os, até mesmo, de "destemperados e moralmente execráveis" minatório do discurso de Bolsonaro parece não ser posto em questão em momento algum por Silva. Além disso, vale observar como para Silva somente seria cabível a atuação judicial "nos casos de responsabilização civil por ofensas à honra perpetradas em situação que não guarde liame com o exercício do mandato" 81 . Visto que o próprio desembargador reconhece, no discurso de Bolsonaro, os abusos na forma de comentários discriminatórios "destemperados e moralmente execráveis", parece estranho que não reconheça eventual ilicitude destes, uma vez que se espera que o exercício do mandato de deputado federal seja incompatível com uma postura intolerante, preconceituosa e ilícita.

Tratando-se, aliás, de caso que poderia ser facilmente reconhecido como discurso de ódio ${ }^{82}$ contra minorias, concordamos com Eleonora Ceia, no sentido de que as "declarações de discurso de ódio contra minorias não sejam acobertadas pela imunidade material, a despeito de serem realizadas no exercício de atividades parlamentares (discursos e votos) e dentro do recinto das Casas Legislativas" ${ }^{83}$. Ou seja, para Ceia, a inviolabilidade parlamentar não deve ser entendida como algo intocável, isto é, como um instituto de natureza absoluta, de modo que este deve ser "relativizado, permitindo a responsabilização posterior do parlamentar, quando a sua manifestação contrariar postulados centrais do Estado Democrático de Direito, quais sejam: a dignidade humana e a proteção das minorias" $"$.

A perspectiva esboçada por Ceia, com a qual concordamos, contraria a percepção de Silva, para quem uma tentativa, como a do MPF, consistiria em mais uma tentativa de substituir uma eventual inação dos órgãos realmente competentes para cercear a conduta de Bolsonaro. É o que afirma o desembargador nesta passagem:

VIII - Não há tentar substituir a (in)ação dos órgãos competentes para cercear condutas maculadas

80 BRASIL. Poder Judiciário. Tribunal Regional da $2^{a}$ Região. Apelação Cível. Turma Especial III. Administrativo e Cível. N. ${ }^{\circ}$ CNJ: 0101298-70.2017.4.02.5101 [2017.51.01.101298-3]. Relator: Desembargador Federal Marcelo Pereira da Silva. Apelante: Ministério Público Federal e outros. Procurador: Procurador Regional da República e outros. Apelado: os mesmos. Origem: 26ª Vara Federal do Rio de Janeiro [01012987020174025101]. Disponível em: <https://www.migalhas.com.br/arquivos/2018/9/art20180925-04. pdf $>$. Acesso em: 12 de abril de 2020, p. 01.

81 BRASIL. Poder Judiciário. Tribunal Regional da $2^{a}$ Região. Apelação Cível. Turma Especial III. Administrativo e Cível. No CNJ: 0101298-70.2017.4.02.5101 [2017.51.01.101298-3]. Relator: Desembargador Federal Marcelo Pereira da Silva. Apelante: Ministério Público Federal e outros. Procurador: Procurador Regional da República e outros. Apelado: os mesmos. Origem: 26ª Vara Federal do Rio de Janeiro [01012987020174025101]. Disponível em: <https://www.migalhas.com.br/arquivos/2018/9/art20180925-04. pdf $>$. Acesso em: 12 de abril de 2020, p. 02.

82 Sobre o tema, interessante observar com Carlo José Napolitano e Tatiana Stroppa que, em uma sociedade multicultural como a brasileira, acentua-se "a necessidade de discutir a amplitude que deve ser conferida à liberdade de expressão e acerca de quais são as respostas constitucionalmente adequadas para combater os discursos de ódio (hate speech)". NAPOLITANO, Carlo José e STROPPA, Tatiana. O Supremo Tribunal Federal e o discurso de ódio nas redes sociais: exercício de direito versus limites à liberdade de expressão. In: Revista Brasileira de Políticas Públicas, Volume 7, N. 3, 2017, pp. 313-332. Disponível em: <https://www.publicacoesacademicas.uniceub.br/RBPP/article/view/4920>. Acesso em: 20 de maio de 2020, p. 323.

83 CEIA, Eleonora Mesquita. Imunidade parlamentar e discurso de ódio no Brasil. In: Raigal. Revista Interdisciplinaria de Ciencias Sociales, N. 3 3, Octubre 2016-marzo 2017 (Sección Dossier, pp. 16-26). Disponível em: <http:/ / socialesinvestiga.unvm.edu.ar/ojs/ index.php/raigal/article/view/109>. Acesso em: 12 de abril de 2020, p. 24.

84 CEIA, Eleonora Mesquita. Imunidade parlamentar e discurso de ódio no Brasil. In: Raigal. Revista Interdisciplinaria de Ciencias Sociales, N. 3 3, Octubre 2016-marzo 2017 (Sección Dossier, pp. 16-26). Disponível em: <http:/ / socialesinvestiga.unvm.edu.ar/ojs/ index.php/raigal/article/view/109>. Acesso em: 12 de abril de 2020, p. 24. 
por possível falta de decoro parlamentar por uma atuação judicial repressora de suas opiniões, palavras ou votos, eis que a Constituição democrática de 1988 expressamente garantiu aos parlamentares eleitos pelo voto popular o direito de se manifestarem livremente, no exercício de seus mandatos, mediante a certeza de sua inviolabilidade, o que exclui a possibilidade de responsabilização civil ou penal de tais indivíduos por possíveis palavras ofensivas dirigidas a pessoas ou grupos no bojo dos discursos por eles proferidos, no exercício de seus mandatos e na defesa de suas convicções políticas.

Possivelmente é pela "certeza de sua inviolabilidade" que Bolsonaro proferiu um discurso marcadamente racista e segregador. O "bojo" do discurso parece tratar-se aqui de um espaço que resguarda não apenas as convicções políticas, mas todas as palavras ofensivas e preconceitos do parlamentar. Segundo entendemos, essa "manifestação livre" do pensamento não deveria ser absoluta, pois, como no caso em comento, o discurso pode causar danos a bens jurídicos igualmente protegidos pelo ordenamento jurídico. Nesse sentido, concordamos com Thiago Coelho Sacchetto: "as manifestações de pensamento externadas pelos discursos de ódio atacam a dignidade de grupos sociais vulneráveis, e, a depender de sua gravidade, caracterizam-se como ataques à própria democracia" $" 85$.

A reprodução inquestionada de certos valores por juízes é algo que Luis Aberto Warat, no âmbito da Crítica do Direito, já denunciou há décadas. Tal reprodução é muitas vezes caracterizada pelo atendimento cego a uma determinada ideologia. Para Warat, "a ideologia se apresenta simultaneamente como uma forma de convencimento da realidade e como um modo de dominação social". Nesse sentido, a dominação é exercida pela imposição de dada ideologia por meio da força ou, como no caso em comento, da persuasão ${ }^{86}$. O perigo de decisões como esta é criar um precedente no Judiciário que amenize os crimes de discriminação e preconceito — seja racial, sexual ou religioso — perpetrados por parlamentares "no exercício de suas funções" ou quando "guardem concordância com sua atividade parlamentar".

Temas como discriminação e racismo geralmente são tratados, explica van Dijk, como se fossem "ressentimentos populares (raramente ou nunca sobre o racismo da elite) sobre casos individuais de discriminação, por exemplo, no trabalho, ou sobre partidos racistas extremistas. Em outras palavras, discriminação e racismo, quando discutidos nos discursos da elite, estão sempre em outro lugar" ${ }^{87}$.

Ademais, no Acórdão em comento, percebe-se tendenciosa seleção, por Silva, de informações relevantes dos modelos de contexto que acabam por regular, de modo habilidoso, as representações semânticas do caso. Agindo assim, não só a ideologia política de Bolsonaro bem como a ideologia jurídica do desembargador (eivadas de questões passíveis de crítica) prevalecem, fortalecendo o cenário de dominação social.

\section{Considerações finais}

O estudo crítico do discurso jurídico deve reconhecer as relações de poder na sociedade, verificando de que forma se mantêm as diferentes relações de dominação e subordinação por parte de certos atores sociais. Para se detectar a existência de grupos dominados, devem-se desvelar os caracteres do discurso dominante, o que possibilita que se revele a legitimidade ou ilegitimidade de determinadas ações discursivas dos diferentes grupos sociais.

O exercício do poder social pressupõe a existência de uma estrutura ideológica, forjada com base em

\footnotetext{
85 SACCHETTO, Thiago Coelho. O Discurso de Ódio na Democracia Brasileira: há direito à representação parlamentar? In: PEREIRA, Rodolfo Viana (Org.). Direitos Políticos, Liberdade de Expressão e Discurso de Ódio. Volume I. Belo Horizonte: Instituto para o Desenvolvimento Democrático, 2018, p. 255.

86 WARAT, Luis Alberto. Introdução Geral ao Direito I. Interpretação da Lei: Temas para uma Reformulação. Porto Alegre: Sérgio Antonio Fabris Editor, 1994, p. 146.

87 DIJK, Teun A. van. Discurso e Poder. Org. Hoffnagel, Judith e Falcone, Karina. $2^{a}$ ed. $1^{\text {a }}$ reimpressão. São Paulo: Contexto, 2012, p. 146.
} 
cognições fundamentais, socialmente compartilhadas, reveladas no discurso. Especificamente em relação ao discurso jurídico, a dimensão ideológica não pode ser ignorada. No entanto, para além da ideologia, é preciso, também, considerar a função que o discurso jurídico muitas vezes tem de mascarar a realidade, utilizando-se da retórica jurídica, convenientemente e no atendimento de seus próprios e nem sempre nítidos interesses.

No caso analisado no presente artigo, foi possível perceber de que forma a decisão judicial de segunda instância, no exercício do seu poder de controle social, manejou as provas contidas nos autos no sentido de estender — para além do possível e do tolerável — o manto da imunidade parlamentar que eximiu Jair Bolsonaro de qualquer responsabilidade civil em relação aos prejuízos provocados por seu discurso discriminatório e racista contra a comunidade quilombola.

A imunidade parlamentar material, no entanto, é uma prerrogativa em função do exercício do cargo eletivo que, assim como o direito à regulamentação do território dos remanescentes das comunidades quilombolas, foi instituído pela Constituição Federal de 1988, no bojo da redemocratização do país, com o objetivo - louvável, reconhecemos — de proteger os parlamentares das perseguições políticas, comuns durante o período em que o país vivia sob o regime de ditadura militar — esta, aliás, defendida por Bolsonaro publicamente.

Ao relativizar os efeitos do discurso de Bolsonaro no Clube Hebraica Rio para a comunidade quilombola e minorar (ou mesmo ignorar), convenientemente, a importância do território para formação da identidade daquele povo, essa decisão revelou a existência, no Judiciário brasileiro, de uma ideologia exercida por meio da dominação-persuasão, com o objetivo de preservar o poder que detém em danosa cumplicidade com a elite racista brasileira.

\section{Referências}

BARROS, Bruno Mello Correa de e ALBRECHT, Rita Mara. A discriminação racial no Brasil e a ascensão do povo negro: um olhar a partir dos princípios constitucionais na luta pela cidadania inclusiva. In: Revista Brasileira de Politicas Públicas, Vol. 9, N. 1, pp. 14-33, 2019. Disponível em: <https://www.publicacoesacademicas.uniceub.br/RBPP/article/view/5908>. Acesso em 19 de maio de 2020.

BIBLIOTECA NACIONAL DIGITAL. Disponível em: < https://bndigital.bn.gov.br/dossies/trafico-de-escravos-no-brasil/acordos-internacionais-e-legislacao-sobre-escravidao $>$. Acesso em: 18 de março de 2020.

BOURDIEU, Pierre. O Poder Simbólico. Trad. de Fernando Tomaz. Rio de Janeiro: Editora Bertrand Brasil, 1989.

BRASIL. Presidência da República. Casa Civil. Subchefia para Assuntos Jurídicos. Lei № 7.716, de 5 de janeiro de 1989. Disponível em: <http://www.planalto.gov.br/ccivil_03/leis/17716.htm>. Acesso em: 16 de março de 2020.

BRASIL. EMI N. 58. Disponível em: <http://www.planalto.gov.br/ccivil_03/Exm/2003/EMI58-CCV-MINC-MDA-SEPPIR-03.htm>. Acesso em 27 de março de 2020.

BRASIL. Lei N. ${ }^{\circ}$ 581, de 4 de Setembro de 1850. Disponível em: < http://www.planalto.gov.br/ccivil_03/ leis/lim/LIM581.htm>. Acesso em: 25 de março de 2020.

BRASIL. Lei N.o 601, de 18 de Setembro de 1850. Disponível em: <http:/ /www.planalto.gov.br/ccivil_03/ LEIS/L0601-1850.htm>. Acesso em: 17 de março de 2020. 
BRASIL. Poder Judiciário. Justiça Federal. Seção Judiciária do Rio de Janeiro. 26 a Vara Federal da Seção Judiciária do Rio de Janeiro. Ação Civil Pública No 0101298-70.2017.4.02.5101. Autores: Ministério Público Federal e outro. Réu: Jair Messias Bolsonaro. Julgador(a): Frana Elizabeth Mendes, Juíza Federal. Rio de Janeiro, 25 de setembro de 2017. Disponível em: < https://politica.estadao.com.br/blogs/fausto-macedo/ wp-content/uploads/sites/41/2017/10/76994222-50-1-pp.pdf>. Acesso em: 15 de abril de 2020.

BRASIL. Poder Judiciário. Tribunal Regional da $2^{a}$ Região. Apelação Cível. Turma Especial III. Administrativo e Cível. N. ${ }^{\circ}$ CNJ: 0101298-70.2017.4.02.5101 [2017.51.01.101298-3]. Relator: Desembargador Federal Marcelo Pereira da Silva. Apelante: Ministério Público Federal e outros. Procurador: Procurador Regional da República e outros. Apelado: os mesmos. Origem: 26a Vara Federal do Rio de Janeiro [01012987020174025101]. Disponível em: <https://www.migalhas.com.br/arquivos/2018/9/art2018092504.pdf $>$. Acesso em: 12 de abril de 2020.

BRASIL. Supremo Tribunal Federal. Primeira Turma. Inquérito N.o 4.694. Distrito Federal. Relator: Ministro Marco Aurélio. Autor: Ministério Público Federal. Proc.(a/s)(es): Procurador-Geral da República. Invest. (a/s): Jair Messias Bolsonaro. Adv. (a/s): Antônio Sérgio Altieri de Moraes Pitombo e outros (a/s). Data: 11/09/2018. Disponível em: <https://stf.jusbrasil.com.br/jurisprudencia/768164396/inquerito-inq-4694-df-distrito-federal-0016317-5720181000000/inteiro-teor-768164398?ref=serp >. Acesso em: 12 de abril de 2020 .

CARNEIRO, Aparecida Sueli. A Construção do Outro como Não-Ser como fundamento do Ser. Tese de Doutorado. São Paulo: Feusp, 2005.

CARONE, Iray e BENTO, Maria Aparecida Silva, (org.). Psicologia Social do Racismo: Estudos sobre branquetude e branqueamento no Brasil. $6^{\text {a }}$ ed. Petropólis: Vozes, 2014.

CEIA, Eleonora Mesquita. Imunidade parlamentar e discurso de ódio no Brasil. In: Raigal. Revista Interdisciplinaria de Ciencias Sociales, N. ${ }^{\circ}$ 3, Octubre 2016-marzo 2017 (Sección Dossier, pp. 16-26). Disponível em: < http://socialesinvestiga.unvm.edu.ar/ojs/index.php/raigal/article/view/109>. Acesso em: $12 \mathrm{de}$ abril de 2020 .

CIOCCARI, Deysi e PERSICHETTI, Simonetta. Armas, ódio e espetáculo em Jair Bolsonaro. In: Revista Alterjor, Grupo de Estudos Alterjor: Jornalismo Popular e Alternativo (ECA-USP) Ano 09, Volume 02, Edição 18, Julho-Dezembro de 2018. Disponível em: <http://www.revistas.usp.br/alterjor/article/view/144688>. Acesso em: 18 de maio de 2020.

CONAQ e Terra de Direitos. Representação ao MPF. Disponível em: < https://terradedireitos.org.br/wp-content/uploads/2017/04/repre.-Bolsonaro.pdf>. Acesso em 27 de março de 2020.

CONGRESSO EM FOCO (UOL). "Reação da comunidade judaica leva a suspensão da palestra de Bolsonaro no Clube Hebraica”. 28 de fevereiro de 2017. Disponível em: <https://congressoemfoco.uol.com.br/especial/noticias/reacao-da-comunidade-judaica-leva-a-suspensao-palestra-de-bolsonaro-no-clube-hebraica/> Acesso em 17 de maio de 2020 .

CONJUR. "MPF-RJ move ação contra Bolsonaro por ataques a negros e quilombolas". Disponível em: <https://www.conjur.com.br/2017-abr-10/mpf-move-acao-bolsonaro-ataques-negros-quilombolas>. Acesso em 27 de março de 2020.

CONLEY, John M. and O’BARR, William M. Just Words: Law, Language and Power. Chicago: The University of Chicago Press, 1998.

DAHRENDORF, Ralf. Homo Sociologicus. Trad. de Freitas e Silva. Lisboa: Quetzal, 2012.

DIJK, Teun A. van (Comp.). El Discurso como Interacción Social. Estudios sobre el discurso II: Una introducción multidisciplinaria. Barcelona: Gedisa, 2008. 
DIJK, Teun A. van. Discurso e Poder. Org. Hoffnagel, Judith e Falcone, Karina. $2^{a}$ ed. $1^{a}$ reimpressão. São Paulo: Contexto, 2012.

DIJK, Teun A. van. Discurso, Notícia e Ideologia: estudos na Análise Crítica do Discurso. Trad. Zara Pinto-Coelho. Colecção Comunicação e Sociedade. Porto: Campo das Letras, 2005.

DIJK, Teun A. van. Ideological Discourse Analysis. In: New Courant (English Dep., University of Helsinki), 4 (1995), pp. 135-161. Special issue Interdisciplinary approaches to Discourse Analysis, ed. by Eija Ventola and Anna Solin.

DIJK, Teun A. van. Opinions and Ideologies in the Press. Paper Round Table on Media Discourse. Cardiff, July 08-10, 1995. In: BELL, Allan and GARRET'T, Peter (Eds.). Approaches to Media Discourse. Oxford: Blackwell, 1998.

DIJK, Teun A. van. Structures of Discourse and Structures of Power. In: ANDERSON, J. A. (Ed.). Communication Yearbook 12, Newbury Park, CA: Sage, 1989.

EL PAÍS. "Os gays não são semideuses. A maioria é fruto do consumo de drogas". Disponível em: <https://brasil. elpais.com/brasil/2014/02/14/politica/1392402426_093148.html>. Acesso em: 27 de março de 2020.

FAIRCLOUGH, Norman. Critical discourse analysis as a method in social scientific research. In: WODAK, Ruth and MEYER, Michael. Methods of Critical Discourse Analysis. London: SAGE Publications, 2002.

FOLHA DE SÃO PAULO. "Entidade judaica condena fala de Bolsonaro em clube". Disponível em: < http:// www1.folha.uol.com.br/poder/2017/04/1873049-entidade-judaica-condena-fala-de-bolsonaro-em-clube. shtml>. Acesso em 27 de março de 2020.

FOLHA DE SÃO PAULO. "Pré-candidato, Bolsonaro tenta criar a 'extrema direita light”. Disponível em: < https:// www1.folha.uol.com.br/poder/2016/06/1779759-pre-candidato-bolsonaro-tenta-criar-a-extrema-direita-light.shtml>. Acesso em 27 de março de 2020.

FOUCAULT, Michel. A Ordem do Discurso. Aula inaugural do Collège de France pronunciada em 2 de dezembro de 1970. São Paulo: Edições Loyola, 2014.

FOWLER, Roger. Power. In: DIJK, Teun A. Handbook of Discourse Analysis, Vol. 4: Discourse Analysis in Society. Orlando: Academic Press, 1985.

G1. "Perfil médio do deputado federal eleito é homem, branco, casado e com ensino superior". Disponível em: <https:/g1.globo.com/politica/eleicoes/2018/eleicao-em-numeros/noticia/2018/10/21/perfil-medio-do-deputado-federal-eleito-e-homem-branco-casado-e-com-ensino-superior.ghtml $>$. Acesso em: 27 de março de 2020.

GHERMAN, Michel e KLEIN, Misha. Entre 'conversos' e 'desconversos': o caso da influência da Nova Direita Brasileira sobre a comunidade judaica do Rio de Janeiro. In: Revista de Estudios Sociales del Estado, V. 5 n. 9, jan-jun 2019, pp. 101-123. Disponível em: < http://www.estudiossocialesdelestado.org/index.php/ ese/article/view/173>. Acesso em 18 de maio de 2020.

HERNÁNDEZ, Tanya Katerí. A Inocência Racial, o Direito Costumeiro e a Nova Resposta dos Direitos Civis. Trad. de Ariovaldo Santos de Souza e Luciana Carvalho Fonseca. Salvador: EDUFBA, 2017.

LIMA, Angela Bernadete. A imigração para o império do Brasil: um olhar sobre os discursos acerca dos imigrantes estrangeiros no século XIX. In: Revista Acadêmica Licencia\&acturas, Ivoti, v.5, n. 2, jul-dez de 2017, pp. 26-36. Disponível em: <http://www.ieduc.org.br/ojs/index.php/licenciaeacturas/article/down$\mathrm{load} / 155 / 130>$. Acesso em: 29 de março de 2020.

MENNA BARRETO, Ricardo de Macedo. Direito, Discurso e Poder: os Media e a Decisão Judicial. Tese de Doutoramento em Ciências Jurídicas Gerais. Escola de Direito, Universidade do Minho, 2019. 
MOREIRA, Adilson. Racismo recreativo. São Paulo: Pólen, 2019.

NAPOLITANO, Carlo José e STROPPA, Tatiana. O Supremo Tribunal Federal e o discurso de ódio nas redes sociais: exercício de direito versus limites à liberdade de expressão. In: Revista Brasileira de Políticas Públicas, Volume 7, N. 3, 2017, pp. 313-332. Disponível em: <https://www.publicacoesacademicas.uniceub.br/ $\mathrm{RBPP} /$ article/view/4920>. Acesso em: 20 de maio de 2020.

NASCIMENTO, Abdias do. O Genocídio do Negro Brasileiro: processo de um racismo mascarado. $3^{\text {a }}$ ed. São Paulo: Perspectiva, 2016.

NASCIMENTO, Germana Aguiar Ribeiro do, BATISTA, Mércia Rejane e Rangel e NASCIMENTO, Marilia Aguiar Ribeiro do. Panorama atual de proteção do direito à terra das comunidades quilombolas e desafios futuros. In: Interações, vol. 17, n.3, Campo Grande, jul-set de 2016, pp. 432-447. Disponível em: <http:// dx.doi.org/10.20435/1984-042X-2016-v.17-n.3(07)>. Acesso em: 20 de março de 2020.

O GLOBO. "Grupo quilombola faz representação contra Jair Bolsonaro por racismo”. Disponível em: <https:/ /oglobo.globo.com/brasil/grupo-quilombola-faz-representacao-contra-jair-bolsonaro-por-racismo-21177099>. Acesso em: 29 de março de 2020.

REGIMENTO DOS CAPITÃES DO MATO, 17/12/1722. In: Atlas Digital da América Lusa. Disponível em: <http://lhs.unb.br/atlas/Regimento_dos_Capitães_do_mato,_17/12/1722>. Acesso em: 16 de março de 2020 .

SACCHETTO, Thiago Coelho. O Discurso de Ódio na Democracia Brasileira: há direito à representação parlamentar? In: PEREIRA, Rodolfo Viana (Org.). Direitos Políticos, Liberdade de Expressão e Discurso de Ódio. Volume I. Belo Horizonte: Instituto para o Desenvolvimento Democrático, 2018.

SANTOS, Fernando do Nascimento. Bolsonaro x Quilombola: racismo recreativo e institucional e a invisibilidade do insulto moral. In: Revista Liberdades, n. 27, IBCCRIM, jan-jun de 2019.

SENADO FEDERAL. "Deputados das bancadas da 'bala, boi e Bíblia' atuam juntos em defesa de interesses próprios e aumentam poder do presidente da Câmara". Disponível em: <https://www2.senado.leg.br/ bdsf/bitstream/handle/id/509963/noticia.html?sequence=1>. Acesso em: 20 de março de 2020.

SILVA, José M. Rodrigues. O Homem e o Poder. Lisboa: Bertrand Editora/Venda Nova, 1988.

SOUZA, Barbara Oliveira. Aquilombar-se: Panorama Histórico, Identitário e Político do Movimento Quilombola Brasileiro. Brasília, 2008.

TERRA DE DIREITOS. “Orçamento para titulação de territórios quilombolas cai mais de 97\% em cinco anos”. Disponível em: < https://terradedireitos.org.br/noticias/noticias/orcamento-para-titulacao-de-territorios-quilombolas-cai-mais-de-97-em-cinco-anos/22824>. Acesso em: 27 de março de 2020.

WARAT, Luis Alberto. Introducão Geral ao Direito I. Interpretação da Lei: Temas para uma Reformulação. Porto Alegre: Sérgio Antonio Fabris Editor, 1994.

WODAK, Ruth. What CDA is about - a summary of its history, important concepts and its developments. In: WODAK, Ruth and MEYER, Michael. Methods of Critical Discourse Analysis. London: SAGE Publications, 2002.

\section{VÍDEOS (YOUTUBE):}

Resposta de Jair Bolsonaro para Preta Gil (Sem Cortes): <https://www.youtube.com/embed/ lkZv3iyZdkA?rel=0>. Acesso em 27 de março de 2020.

Bolsonaro (PP-RJ) x Maria do Rosário (PT-RS). Disponível em: < https://www.youtube.com/embed/ atKHN_irOsQ? rel=0>. Acesso em: 27 de março de 2020. 
Jair Bolsonaro (PP-RJ) ofende Ministra Eleonora Menicucci (PT-MG). Disponível em: < https://www.youtube.com/embed/Do6nXV59ZzE?rel=0>. Acesso em: 27 de março de 2020.

Bolsonaro: "Sou a favor da tortura, golpe militar, fechar o congresso nacional e matar inocentes". Disponível em: < https://www.youtube.com/watch?v=ihvl497x37c>. Acesso em: 25 de março de 2020.

03/04/2017 - Jair Bolsonaro - Palestra no Hebraica Rio de Janeiro. Disponível em: < https://www.youtube. com/watch?v=LPj4KyLw8Wc $>$. Acesso em: 15 de março de 2020.

Bolsonaro exalta Ustra na votação do impeachment em 2016. Disponível em: < https://www.youtube.com/ watch?v=xiAZn7bUC8A>. Acesso em: 25 de março de 2020. 
Para publicar na revista Brasileira de Políticas Públicas, acesse o endereço eletrônico www.rbpp.uniceub.br

Observe as normas de publicação, para facilitar e agilizar o trabalho de edição. 